\title{
Characterization of olivine fabrics and mylonite in the presence of fluid and implications for seismic anisotropy and shear localization
}

Sejin Jung ${ }^{1}$, Haemyeong Jung ${ }^{1 *}$ and Håkon Austrheim²

\begin{abstract}
The Lindås Nappe, Bergen Arc, is located in western Norway and displays two high-grade metamorphic structures. A Precambrian granulite facies foliation is transected by Caledonian fluid-induced eclogite-facies shear zones and pseudotachylytes. To understand how a superimposed tectonic event may influence olivine fabric and change seismic anisotropy, two lenses of spinel Iherzolite were studied by scanning electron microscope (SEM) and electron back-scattered diffraction (EBSD) techniques. The granulite foliation of the surrounding anorthosite complex is displayed in ultramafic lenses as a modal variation in olivine, pyroxenes, and spinel, and the Caledonian eclogite-facies structure in the surrounding anorthosite gabbro is represented by thin $(<1 \mathrm{~cm})$ garnet-bearing ultramylonite zones. The olivine fabrics in the spinel bearing assemblage were E-type and B-type and a combination of A- and B-type lattice preferred orientations (LPOs). There was a change in olivine fabric from a combination of A- and B-type LPOs in the spinel bearing assemblage to B- and E-type LPOs in the garnet Iherzolite mylonite zones. Fourier transform infrared (FTIR) spectroscopy analyses reveal that the water content of olivine in mylonite is much higher (approximately $600 \mathrm{ppm} \mathrm{H/Si)} \mathrm{than} \mathrm{that} \mathrm{in} \mathrm{spinel} \mathrm{Iherzolite} \mathrm{(approximately} 350 \mathrm{ppm} \mathrm{H/Si),} \mathrm{indicating} \mathrm{that}$ water caused the difference in olivine fabric. Fabric strength of olivine gets weaker as the grain size reduced, and as a result, calculated seismic properties for the two deformation stages reveal that P- and S-velocity anisotropies are significantly weaker in the mylonite. Microtextures and LPO data indicate that the deformation mechanism changed from dominant dislocation creep in spinel Iherzolite to dislocation creep accompanied by grain-boundary sliding in mylonite. Shear localization in the mylonite appears to be originated from the grain size reduction through (1) enhanced dynamic recrystallization of olivine in the presence of water and (2) Zener pinning of clinopyroxene or (3) by ultracomminution during the pseudotachylyte stage.
\end{abstract}

\section{Background}

Olivine is a dominant mineral in the upper mantle. Knowledge of the lattice preferred orientation (LPO) of olivine can be used to understand mantle flow and the seismic anisotropy of the upper mantle (Nicolas and Christensen 1987; Ben Ismail and Mainprice 1998; Long 2013). The water content of olivine is one of the most important factors affecting olivine LPO (Jung and Karato 2001a). In the early studies, olivine fabric in upper mantle conditions thought to be dominated by one type of olivine LPO in upper mantle conditions (Ben Ismail and Mainprice 1998; Nicolas and Christensen 1987), which is later named as

\footnotetext{
* Correspondence: hjung@snu.ac.kr

${ }^{1}$ School of Earth and Environment Sciences, Seoul National University, Seoul 151-747, South Korea

Full list of author information is available at the end of the article
}

A-type (Jung and Karato 2001a). However, recent experimental studies (Jung and Karato 2001a; Jung et al. 2006; Karato et al. 2008; Katayama et al. 2004) show that A-, B-, $\mathrm{C}$-, and E-types of olivine LPO can be observed under different deformation conditions. The relationship between olivine LPO and the water content of olivine has been established (Jung et al. 2006). Under dry conditions, A-type olivine LPO is observed and, characteristically, the [100] axes are aligned subparallel to lineation, and the [010] axes are aligned normal to foliation. Under water-rich conditions, olivine LPO can change to B-, C-, or E-types LPOs (Jung and Karato 2001a; Jung et al. 2006). For the B-type LPO, the [001] axes are aligned subparallel to lineation and the [010] axes are aligned normal to the foliation. For the C-type LPO, the [001] axes are 
subparallel to lineation and the [100] axes are normal to foliation. For the E-type LPO, the [100] axes are subparallel to lineation and the [001] axes are normal to foliation.

Water-related olivine fabrics have been reported in some natural peridotites. For example, Frese et al. (2003) reported that prograde garnet peridotite from Cima di Gagnone in the Central Alps (Switzerland) has the C-type LPO of olivine. Mehl et al. (2003) found that peridotite from Talkeetna arc in the south central Alaska (USA) has the E-type LPO of olivine. Katayama et al. (2005) found that garnet peridotite from Otrøy in the Western Gneiss Region (Norway) has the C-type LPO of olivine. Michibayashi et al. (2007) reported that peridotites from the southern Mariana trench have B-type LPO of olivine. Webber et al. (2008) noted that mantle peridotites from Red Hills (New Zealand) also have the B-type LPO of olivine. Jung (2009) reported that peridotites from Val Malenco (Italy) have both B- and E-type olivine LPO. Park et al. (2014) recently reported that spinel peridotites from Adam's Diggings, Rio Grande Rift (USA) contain C-type LPO of olivine. Jung et al. (2013) reported that peridotites from North Qaidam UHP collision belt (China) have C-type olivine LPO with olivine containing a large amount of water $(1,130 \pm 50 \mathrm{ppm} \mathrm{H} / \mathrm{Si})$. Park and Jung (2014) recently reported the B- and E-type LPO of olivine in the mantle xenoliths from Shanwang, eastern China. However, the effects of water and dynamic recrystallization on olivine fabric strength and two-stage deformations under water-rich conditions on seismic anisotropy are not yet well understood.

To use mantle fabrics to decipher plate movements, it is important to understand the timing of fabric development. This issue is closely linked to understanding mantle anisotropy, where studies of this topic generally assume that seismic anisotropy developed during a single tectonic event. Lindås Nappe, located in western Norway, contains rocks exposed to eclogite-facies conditions, and the anorthosites in this area possess two fabrics. Grenvillian granulite facies rocks are transected by eclogite-facies shear zones that developed during the Caledonian collision between Baltica and Lurentia. Lindås Nappe contains numerous small peridotite lenses that allow us to investigate fabric development in peridotites exposed to two high-grade metamorphic events with different amounts of fluid. Fluids may also promote metamorphic reactions, like transformation from spinel peridotite to garnet peridotite. Metamorphic reactions and changes in mineral assemblages can be associated with a change in fabric.

We show here that the peridotites, like the anorthosites, display two fabrics of different strengths and that these differences can be related to the water content of olivine. Microstructures are used to infer the deformation mechanism of olivine. Dislocation microstructures of olivine for the two structures are also reported. Consequences of our findings are discussed in relation to shear localization and seismic anisotropy in the upper mantle. Shear localization may have been initiated by intermediate deep earthquakes represented by pseudotachylytes. The earthquakes induced inhomogeneity in the rock through ultracomminution and allowed fluid influx.

\section{Geological setting and sample description}

Bergen Arc is composed of several Nappe units that are distributed in an arc shape and centered on the town of Bergen, Western Norway (Figure 1A). Lindås Nappe is the largest of these units. It is believed that the eclogite facies overprinting occurred when Lindås Nappe formed part of the root zone to the Caledonian mountain belt (Austrheim 1987; Austrheim et al. 1997; Boundy et al. 1997). The main component of Lindås Nappe is anorthosite and includes other members of the anorthosite-mangeritegranite-charnockite (AMGC) suite of rocks (Austrheim 1990). The Lindås Nappe anorthosite complex has undergone two main phases of metamorphism and deformation - the Grenvillian orogeny and the Caledonian orogeny. During the Grenvillian orogeny, the complex developed a dry granulite-facies mineralogy $\left(800^{\circ} \mathrm{C}\right.$ to $900^{\circ} \mathrm{C},<1 \mathrm{GPa}$ ) (Austrheim and Griffin 1985) and a granulite-facies foliation. Typically, this foliation is characterized by disc-shaped coronas that are oriented in the same direction and by alternating plagioclase-rich and mafic layers that produce a strong banding. The granulitefacies anorthositic rocks were transformed, locally, to dense eclogite-facies rocks during the Caledonian orogeny $\left(650^{\circ} \mathrm{C}\right.$ to $700^{\circ} \mathrm{C}, 1.5$ to $2.1 \mathrm{GPa}$ ) (Jamtveit et al. 1990; Glodny et al. 2008).

Eclogitization during the Caledonian orogeny is associated with deformation and fluid infiltration (Austrheim 1987). Eclogites are formed along fractures and shear zones, and in breccias, where angular blocks of granulites are surrounded by eclogite. The Lindås Nappe anorthosite complex can be classified based on the percentage of eclogite - under $40 \%, 40 \%$ to $80 \%$, and over $80 \%$ (Austrheim 1990). In the anorthositic rock body, there are a large number of pseudotachylyte veins that contain evidence of deep crustal seismic activity (Austrheim and Boundy 1994; Austrheim et al. 1996). The exact time of this seismic activity is unclear, but it must have taken place before or syn-eclogite facies metamorphism since the veins display an eclogite facies mineralogy.

The northwest part of the island of Holsnøy is a part of Lindås Nappe. Within this region, there are numerous strongly banded ultramafic lenses, typically 5 to $50 \mathrm{~m}$ across. They consist of lherzolites interlayered with websterites and garnet pyroxenites. Calculated equilibrium $\mathrm{P}-\mathrm{T}$ conditions and age data of these lenses (Kühn et al. 2000) give $1 \mathrm{GPa}, 743^{\circ} \mathrm{C}$ to $977^{\circ} \mathrm{C}$, and $842 \pm 12 \mathrm{Ma}$, which are consistent with those of the Grenvillian granulite-facies 


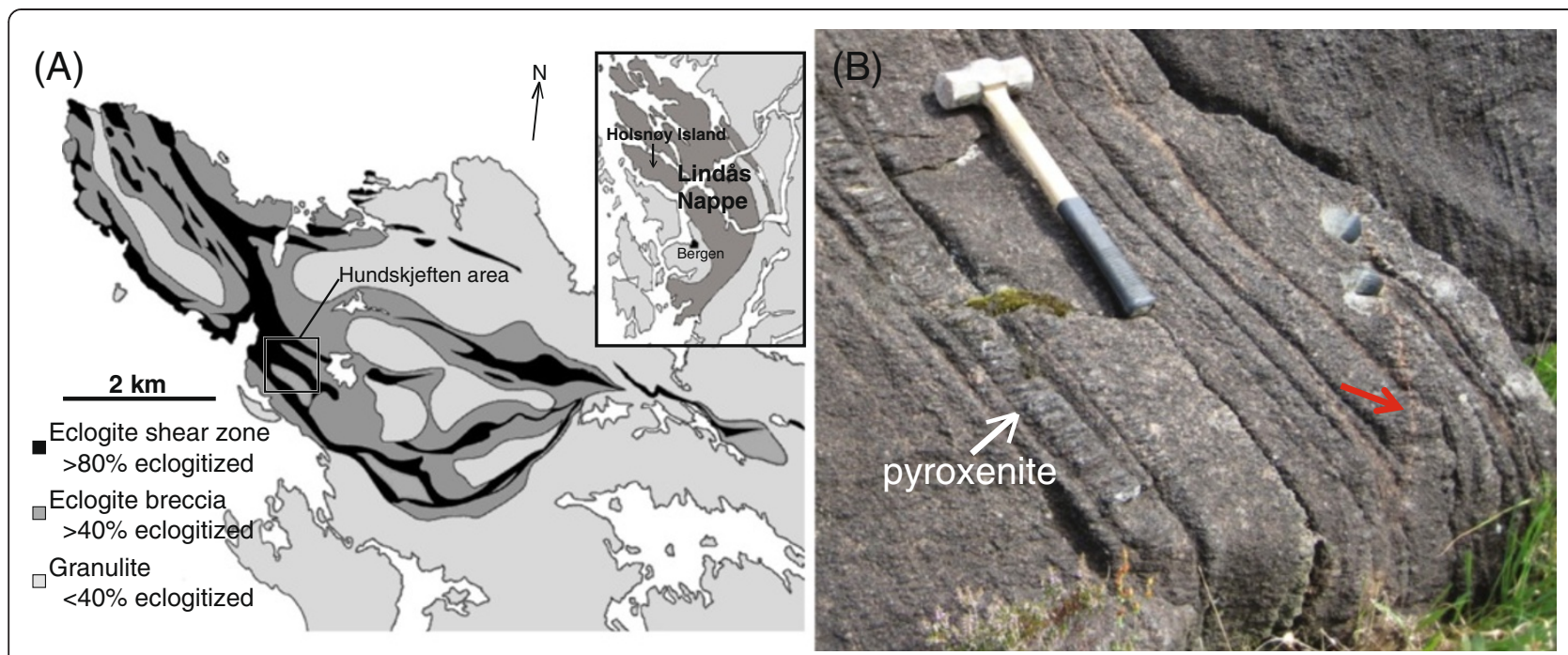

Figure 1 Geological maps and a picture of the outcrop. (A) Geological maps of Lindås Nappe and the northwest part of Holsnøy Island showing the distribution of granulite and eclogite. Geological maps presented here are modified after Austrheim et al. (1996), Boundy et al. (1997), and Pollok et al. (2008). (B) A picture of the Hundskjeften peridotite outcrop. Note the compositional layering of pyroxenite in the peridotite. The mylonite structure is indicated by a red arrow. The length of the hammer in the picture is $50 \mathrm{~cm}$.

metamorphism recorded in surrounding anorthositic rocks (Austrheim and Griffin 1985). As with the surrounding anorthositic rocks, the ultramafic rocks were also affected by high-pressure metamorphism during the Caledonian orogeny and transformed from spinel lherzolite to garnet lherzolite with hydrous and carbonaceous phases (Kühn et al. 2000).

The samples used in our study were collected from the Hundskjeften area on the island of Holsnøy at a location where the surrounding anorthositic rocks formed an eclogite-facies breccia (Austrheim 1990) (Figure 1A, Additional file 1: Figure S1). The breccia is composed of granulite blocks surrounded by eclogite-facies shear zones where eclogite constitutes about $50 \%$ by volume. This area is transected by larger eclogite-facies shear zones $(100 \mathrm{~m}$ wide) where eclogite constitutes up to $80 \%$ of the material in the shear zone (Figure 1A). Internal foliation within the ultramafic blocks (Figure 1B) consists of compositional bands defined by modal variations in olivine-pyroxene and pyroxene-garnet content. Mylonite structures are observed in two ultramafic bodies (Figure 1B). Morphology of the mylonite structures is similar to that of the pseudotachylyte veins which are observed within the anorthosite, indicating close relationship between two structures. The wall rock fabric is Grenvillian in age (ca. $930 \mathrm{Ma}$ ), while the mylonite zone is Caledonian in age (ca. $430 \mathrm{Ma}$ ) (Bingen et al. 2001; Glodny et al. 2008). Similar mylonite structures in ultramafic rocks are reported to exist at various localities, such as Balmuccia Peridotite, Italy (Ueda et al. 2008), Hilti Massif, Josephine Peridotite, USA (Skemer et al. 2010,
2013), Oman (Linckens et al. 2011; Michibayashi and Oohara 2013), and Étang de Lers, France (Drury et al. 2011). In this study, six samples from two different peridotite outcrops were analyzed. Thin $(0.5 \mathrm{~cm}$ across $)$ mylonite zones are present in two samples, 379 and 380. The mylonite zones appear as a brownish-red line on a weathered surface (Figure 1B); a red arrow points to this feature in the figure. On the basis of grain size, the peridotite sample can be divided into three different areas: large, medium, and small grained. The large-grained area represents the wall rock part of peridotite (Figure 2A). The average grain size of wall rock ranges 1.2 to $2.0 \mathrm{~mm}$ (Table 1). The medium-grained area represents the largergrained layer within the mylonite zone, and the smallgrained area represents the smaller-grained layer within the mylonite zone (Figure 2G). Average grain size is in the range 51 to $53 \mu \mathrm{m}$ for the medium-grained area and 9 to $10 \mu \mathrm{m}$ for the small-grained area (Table 1). The mediumand small-grained areas form thin layers interlayering each other. The LPO of olivine and other minerals were analyzed separately for each of the three areas.

\section{Methods}

\section{Measurement of LPO}

Foliation of samples from the large-grained (wall rock) area was determined as a compositional layering defined by modal variation of orthopyroxene (opx), clinopyroxene (cpx), garnet, and olivine (Figure 1B). Note that garnet is confined to the pyroxene rich parts as a garnet pyroxenite and is not in equilibrium with olivine (Kühn et al. 2000). Lineation was determined by examining the 

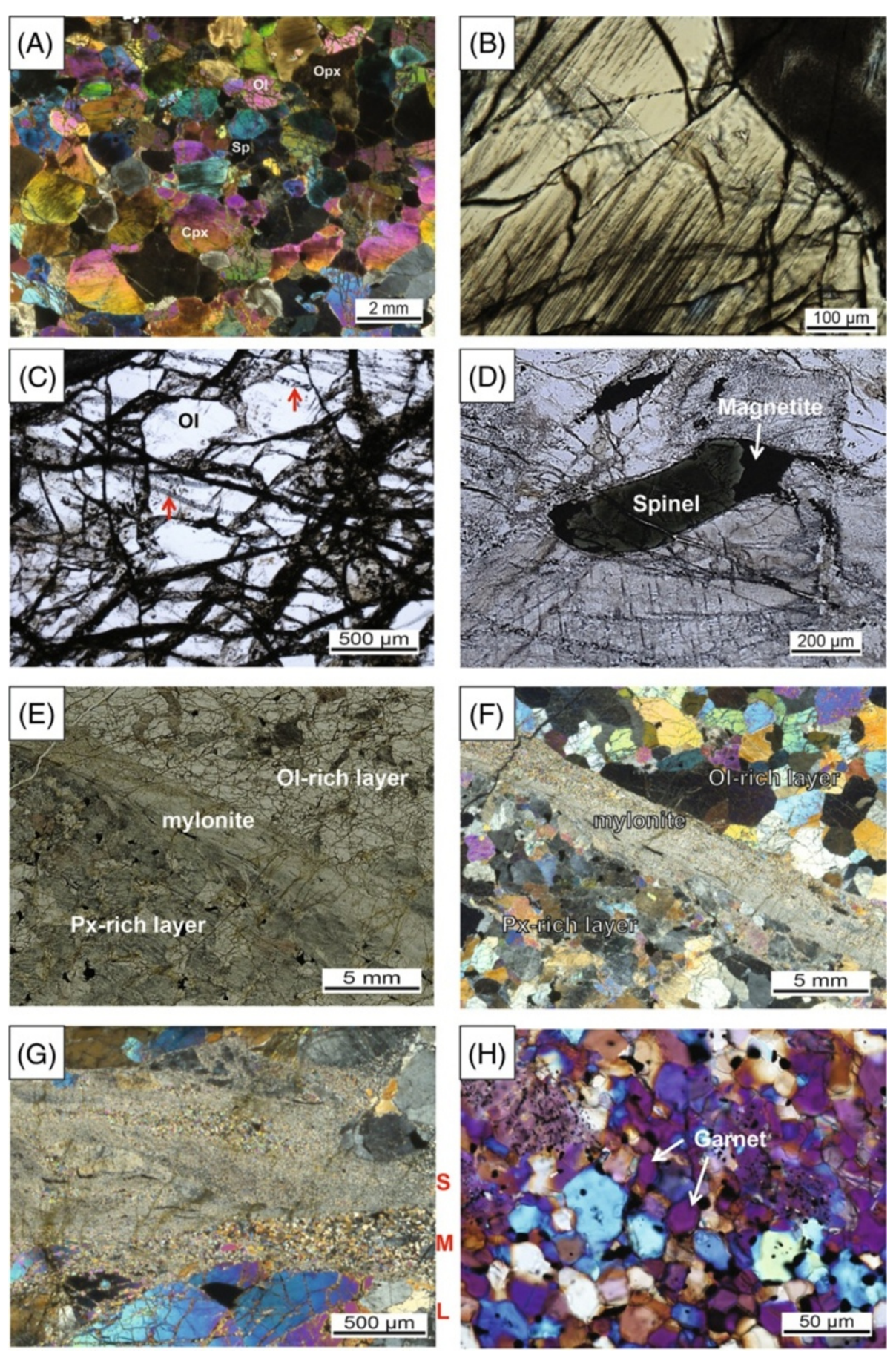

Figure 2 Optical photomicrographs of samples in transmitted light. (A) Sample consists of olivine (ol), orthopyroxene (opx), and clinopyroxene (cpx) with minor spinel (sp) and shows a protogranular texture. (B) Dark inclusions in opx (sample 381). Inclusions are common in opx and cpx and are aligned along a plane parallel to (010) or (001) (Nesse 2004). (C) Black inclusions are found as a trail in the olivine grain (marked with a red arrows; sample 379). (D) Spinel to magnetite transition (sample 379). (E) Unpolarized image of the Ol-rich layer and px-rich layer (px, pyroxene) cut by mylonite (sample 379). (F) Cross-polarized image of the same area as shown in Figure 2E (sample 379). Horizontal direction in the image is parallel to the lineation of wall rock, and vertical direction is normal to the foliation of wall rock. (G) Mylonite in contact with the ol-rich large-grained area (L) (sample 379), consisting of two layers: one with the medium-grained area (M) and the other with the small-grained area (S). (H) Garnet grains found in the small-grained area (sample 379). This picture was taken with a $\lambda$ plate. 
Table 1 Sample description and results

\begin{tabular}{|c|c|c|c|c|c|c|c|c|c|c|c|}
\hline \multicolumn{2}{|l|}{ Sample } & \multirow[t]{2}{*}{372} & \multirow[t]{2}{*}{373} & \multirow[t]{2}{*}{374} & \multicolumn{3}{|c|}{379} & \multicolumn{3}{|c|}{380} & \multirow[t]{2}{*}{381} \\
\hline & & & & & $\mathbf{L}$ & $M$ & $\mathrm{~s}$ & $\mathbf{L}$ & $M$ & 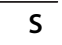 & \\
\hline \multirow[t]{4}{*}{ Modal composition (\%) $)^{a}$} & ol & 10 & 33 & 18 & 61 & 97 & 64 & 35 & 57 & 50 & 30 \\
\hline & opx & 76 & 14 & 33 & 3 & 3 & 3 & 7 & 4 & 5 & 6 \\
\hline & cpx & 13 & 50 & 45 & 35 & 0 & 33 & 55 & 39 & 45 & 61 \\
\hline & $\mathrm{sp}$ & 1 & 3 & 4 & 1 & 0 & 0 & 3 & 0 & 0 & 3 \\
\hline \multicolumn{2}{|c|}{ LPO of olivine ${ }^{b}$} & $\mathrm{E}$ & $A+B$ & B & $A+B$ & (100) [010] & B & $A+B$ & $\mathrm{E}$ & - & $A+B$ \\
\hline \multicolumn{2}{|l|}{ M-index ${ }^{c}$} & 0.27 & 0.08 & 0.17 & 0.1 & 0.06 & 0.04 & 0.06 & 0.04 & 0.04 & 0.1 \\
\hline \multicolumn{2}{|c|}{ Water content 3,620 to $3,500 \mathrm{~cm}^{-1 \mathrm{~d}}(\mathrm{ppm} \mathrm{H} / \mathrm{Si})$} & 240 & 230 & 240 & 90 & 280 & - & 90 & 210 & - & 110 \\
\hline \multicolumn{2}{|c|}{ Water content 3,750 to $3,400 \mathrm{~cm}^{-1 e}(\mathrm{ppm} \mathrm{H} / \mathrm{Si})$} & 400 & 430 & 370 & 110 & 600 & - & 320 & 400 & - & 320 \\
\hline \multicolumn{2}{|c|}{ Average grain size $(\mu \mathrm{m})$} & 2,090 & 1,470 & 1,620 & 1,270 & 53 & 9 & 1,670 & 50 & 10 & 1,240 \\
\hline \multicolumn{2}{|c|}{ Max. Vp anisotropy (\%) } & 3.2 & 4.7 & 4.2 & 6.8 & 7.5 & 2.2 & 3.4 & 2.9 & 1.4 & 3.5 \\
\hline \multicolumn{2}{|c|}{ Max. Vs anisotropy (\%) } & 2.37 & 2.94 & 2.43 & 3.77 & 5.20 & 1.33 & 1.94 & 1.86 & 0.92 & 3.19 \\
\hline \multicolumn{2}{|c|}{ Vp/Ns ratio } & 1.7 & 1.74 & 1.72 & 1.77 & 1.75 & 1.73 & 1.71 & 1.73 & 1.73 & 1.73 \\
\hline
\end{tabular}

Ol, olivine; sp, spinel. L, M, and S represent large-grained (wall rock), medium-grained, and small-grained areas, respectively. Medium- and small-grained areas belong to the mylonite zone. ${ }^{a}$ Garnet grains were found as an accessory mineral in the small-grained area. ${ }^{\text {b}}$ The LPO of olivine classified in a previous experimental study (Jung et al. 2006). ' The M-index represents the fabric strength of olivine (Skemer et al. 2005). d,eThe water content of olivine was calculated using Paterson's calibration (Paterson 1982), using the IR bands between 3,620 to $3,500 \mathrm{~cm}^{-1}$ (d) and 3,750 to $3,400 \mathrm{~cm}^{-1}$ (e). Each result for water content is an average of 10 grains and excludes cracks and inclusions and uncertainty of water content is $\pm 50 \mathrm{ppm} \mathrm{H} / \mathrm{Si}$. ${ }^{\mathrm{f}}$ Grain sizes for both the medium- and small-grained areas were determined by the linear intercept method (Gifkins 1970).

shape-preferred orientation of minerals in foliation using the projection-function method (Panozzo 1984). For samples from the mylonite zone, foliation and lineation were determined independently of the wall rock area. The mylonite layer itself was defined as foliation of the mylonite zone, and lineation for the mylonite zone was determined using the same method as applied to the wall rock area. After lineation and foliation were determined, a thin section was prepared in the $\mathrm{x}-\mathrm{z}$ plane ( $\mathrm{x}$, lineation; $\mathrm{z}$, normal to foliation) to study the LPO of minerals. An electron back-scattered diffraction (EBSD) detector attached to a scanning electron microscope (SEM) (JEOL JSM-6380) housed at the School of Earth and Environmental Sciences (SEES) in Seoul National University (SNU) was used to determine the LPO of each mineral. For the EBSD analysis, we used an HKL system with Channel 5 software. The accelerating voltage was $20 \mathrm{kV}$, and the working distance in the SEM was $15 \mathrm{~mm}$. The EBSD pattern of an individual grain was analyzed manually to ensure an accurate solution. To estimate the fabric strength of the LPO, M-index proposed by Skemer et al. (2005) was used because it is insensitive to the number of grain measured and arbitrary numerical parameters compared to the J-index (Skemer et al. 2005). M-index ranges from 0 to 1:0 for the random fabric and 1 for the single crystal.

\section{FTIR study}

Fourier transform infrared (FTIR) spectroscopy was used to measure water content in olivine and other minerals. Samples were polished on both sides to obtain a thickness of 100 to $180 \mu \mathrm{m}$ for wall rock samples and 40 to $70 \mu \mathrm{m}$ for mylonite samples (Table 1). After polishing, each sample was heated at temperature $T=120^{\circ} \mathrm{C}$ for $24 \mathrm{~h}$ to eliminate water from the surface or grain boundary. A Nicolet 6700 FTIR spectrometer with a continuum IR microscope housed at Tectonophysics laboratory in SEES in SNU was used with unpolarized transmitted light to collect FTIR spectra. An infrared aperture was placed on a single crystal without any cracks or inclusions. The aperture size was set to $50 \mu \mathrm{m} \times 50 \mu \mathrm{m}$ for the large-grained area and $30 \mu \mathrm{m} \times 30 \mu \mathrm{m}$ for the medium-grained area in mylonites. The measurements were carried out using a $\mathrm{KBr}$ beamsplitter and an MCT detector. A series of 128 scans was averaged for each spectrum with a resolution of $4 \mathrm{~cm}^{-1}$. The water content of olivine was calculated using the calibration method described by Paterson (1982) to be comparable to previous studies on olivine LPO under wet conditions (Jung and Karato 2001a; Jung et al. 2006) who also used Paterson's calibration. The same data using the Bell et al. (2003) calibration would yield a value approximately 3.5 times higher. Water content of olivine was calculated in two different ranges: 3,620 to $3,500 \mathrm{~cm}^{-1}$ to consider IR bends only related to the intra-crystalline $\mathrm{OH}$ in olivine and 3,750 to $3,400 \mathrm{~cm}^{-1}$ to include the influence of sub-micrometer scale hydrous minerals in olivine (Table 1). For each sample, FTIR spectra were collected from 10 different grains and averaged.

\section{Dislocation microstructure}

To observe the dislocation microstructures in olivine, an oxygen decoration technique (Kohlstedt et al. 1976) was 
applied. For oxidation, samples were heated in air for $1 \mathrm{~h}$ at $T=800^{\circ} \mathrm{C}$. After oxidation, each sample was polished with colloidal silica to remove a thin oxide from its surface. Polished samples were coated with carbon to prevent charging in the SEM JEOL JSM-6380, and backscattered electron images (BEI) were taken to observe the dislocation microstructures in olivine (Karato 1987; Jung and Karato 2001b). The accelerating voltage was $15 \mathrm{kV}$, and the working distance was $10 \mathrm{~mm}$.

\section{Micro-Raman study}

Micro-Raman spectroscopy was used to identify inclusions inside olivine and pyroxene grains. Raman spectra were obtained using a confocal DXR Raman microscope housed at Tectonophysics laboratory in SEES in SNU. An Ar laser with a wavelength of $532 \mathrm{~nm}$ and a power of $10 \mathrm{~mW}$ was used. Each Raman spectrum was duplicated 32 times, so that the diffraction spectrum could easily be distinguished from noise.

\section{Results}

\section{Microstructures}

The modal composition of each sample is listed in Table 1. The peridotites can be divided into two layers: pyroxenerich and olivine-rich (Figures 2A,E,F). The pyroxene-rich layer consists of olivine ( $10 \%$ to $33 \%$ ), opx (3\% to $76 \%$ ), cpx (13\% to $61 \%$ ), and minor amounts of spinel (Table 1 , Figure 2D). This layer has a protogranular texture (Mercier and Nicolas 1975). The grain size of olivine and pyroxene was coarse (1 to $4 \mathrm{~mm}$ ), and the grain shape was almost round. Undulose extinction was common in both opx and cpx but rare in olivine. An olivine-rich layer was found in samples 379 and 380, and in both samples, the layer was transected by mylonite zones. The olivine-rich layer consists primarily of olivine (>90\%) (Figures 2E,F) and has a tabular equigranular texture (Mercier and Nicolas 1975). Minor amount of spinel is also present in olivine-rich layer (Table 1$)$. The grain size was coarse (1 to $4 \mathrm{~mm}$ ), and grains were elongated parallel to lineation. Grain boundaries clearly showed many triple junctions, and grains showing undulose extinction were rare.

Almost all pyroxene grains in this study contained aligned dot-like opaque exsolution features (Figure 2B). These aligned inclusions are believed to be the main reason that most samples appear black. The grain boundaries were also filled with a black-colored oxide. In samples 372 and 374, there were needle-shaped inclusions in olivine (Figure 3C, photomicrograph image next to the IR spectrum) similar to those reported by Khisina et al. (2001) and (Jung 2009). In the olivine-rich layer, black opaque inclusions were frequently found inside olivine grains. These inclusions were elongated and aligned to form a trail (Figure 2C).
Mylonites were characterized by a very fine grain size (Figure 2F,G). As shown in Figure 2G, a mediumgrained area $(\mathrm{M})$ is interlayered with a small-grained area (S). The medium-grained areas consist mainly of olivine (57\% to $97 \%)$ and cpx (0\% to $39 \%)$. The smallgrained areas consists olivine (50\% to 64\%), cpx (33\% to $43 \%)$, opx (3\% to $4 \%$ ), and minor amounts of garnet (Figure 2H). Mylonite shear plane crosscuts the wall rock foliation plane about $20^{\circ}$ to $30^{\circ}$ (Figure 2E,F). Spinels were present in the wall rock, while small garnets were found around the spinel in the mylonite zone. This suggests that the fabric in the wall rock developed in the spinel lherzolite field, while the mylonite fabric evolved under garnet lherzolite conditions. Regardless of grain size, the mylonite part had a mosaic equigranular texture with a few relict olivine or opx porphyroclasts. These grains in the matrix had a round shape with a small elongation. As in the case of the wall rock, there were many inclusions found inside olivine grains. They were mostly round and transparent inclusions, but black-colored opaque minerals were also commonly found.

\section{LPO of minerals \\ LPO of olivine}

The LPOs of olivine in the large-grained area of the wall rock were plotted in pole figures (Figure 4). Sample 372 shows that the [100] axes of olivine are aligned subparallel to lineation and the [001] axes are aligned subnormal to foliation. These alignments mean that sample 372 has an E-type LPO (Jung et al. 2006; Katayama et al. 2004). Sample 374 shows that the [001] axes of olivine are aligned subparallel to lineation and the [010] axes are aligned subnormal to foliation, which is called B-type LPO (Jung and Karato 2001a; Jung et al. 2006). Other samples showed a combination of two different types of LPO. In samples 373, 379, 380, and 381, both [100] and [001] axes of olivine are aligned subparallel to lineation, and the [010] axes are aligned subnormal to foliation. Thus, the LPO of olivine for these samples is a combination of the A- and B-types (Jung and Karato 2001a) which is defined as A+B type LPO (Table 1).

The LPOs of olivine in mylonite were plotted in pole figures as well (Figure 5). In samples 379 and 380, the LPO of olivine in the mylonite zone is different from that in the wall rock (Figure 5). In the medium-grained area of sample 379, the [100] axes are aligned subnormal to foliation and the [010] axes are aligned subparallel to lineation (Figure 5A). In the small-grained area, the [001] axes of olivine are aligned subparallel to lineation and the [010] axes are aligned subnormal to foliation (Figure 5A), which corresponds to the B-type LPO of olivine (Jung and Karato 2001a). In the medium-grained 

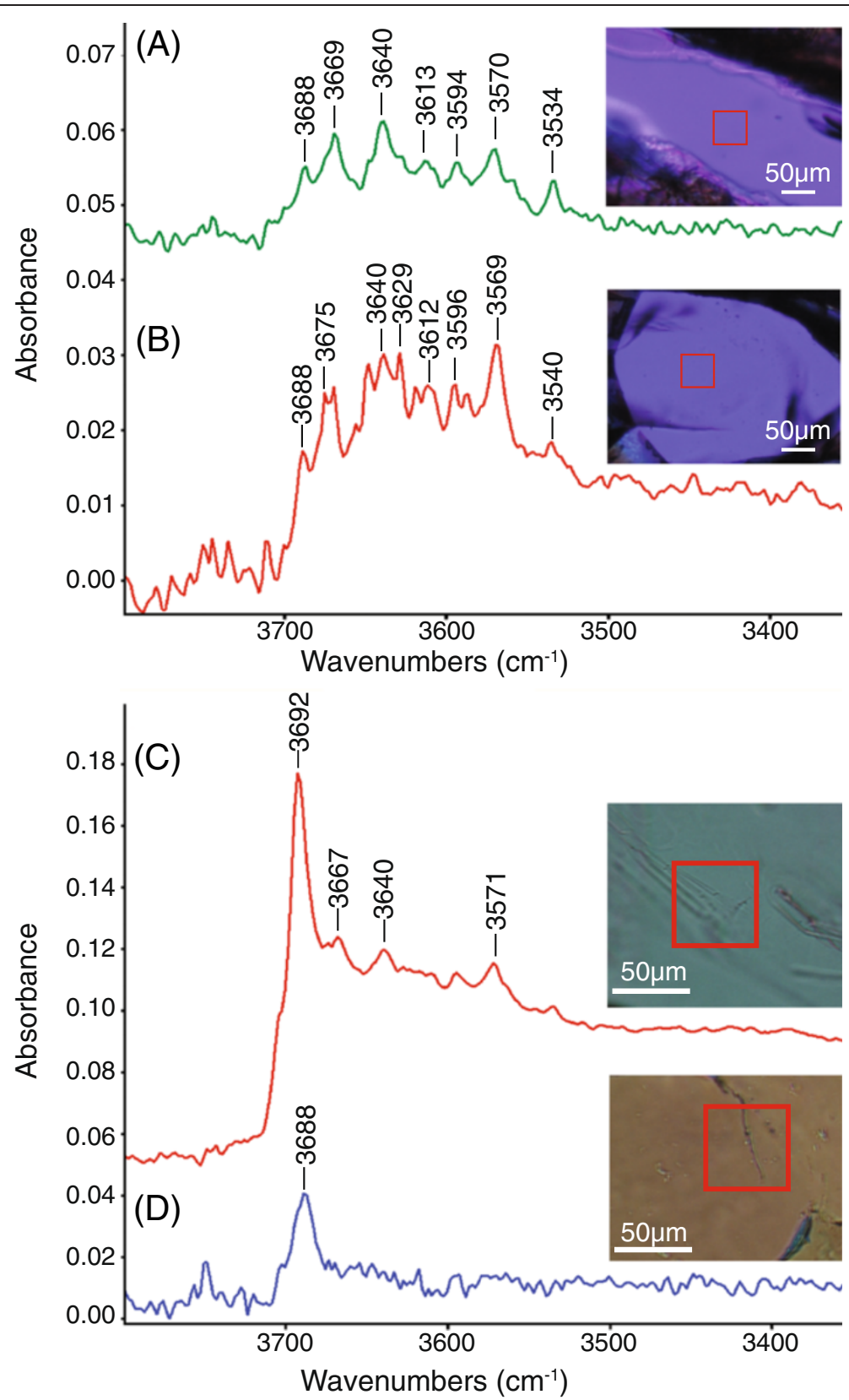

Figure 3 Representative unpolarized FTIR spectra of olivine. Optical photomicrographs next to each FTIR spectra indicate the location where each FTIR spectra were taken. The square in the optical photomicrograph shows the IR beam size of $50 \mu \mathrm{m} \times 50 \mu \mathrm{m}$. (A) FTIR spectrum of olivine in the large-grained area without any inclusion and grain boundary (sample 373). (B) FTIR spectrum of olivine in the large-grained area without any inclusion and grain boundary (sample 372). (C) Unpolarized FTIR spectrum of olivine in the large-grained area (sample 372) where hydrous inclusions are found. (D) Unpolarized FTIR spectrum of olivine in the medium-grained area (sample 380) where a hydrous inclusion (antigorite) is found.

area of sample 380, the [100] axes of olivine are aligned subparallel to lineation and [001] axes are aligned subnormal to foliation (Figure 5B), which corresponds to the E-type LPO of olivine. On the other hand, olivine in the small-grained area showed a weak LPO and thus it is hard to determine its type (Figure 5B).
The fabric strengths (M-index) of samples are listed in Table 1. The M-index of samples in the wall rock area ranged from 0.06 to 0.27 . The M-index of samples in the mylonite zone was much lower than that in the wall rocks, meaning a weaker LPO in the mylonite. The M-index of the medium-grained area ranged from 


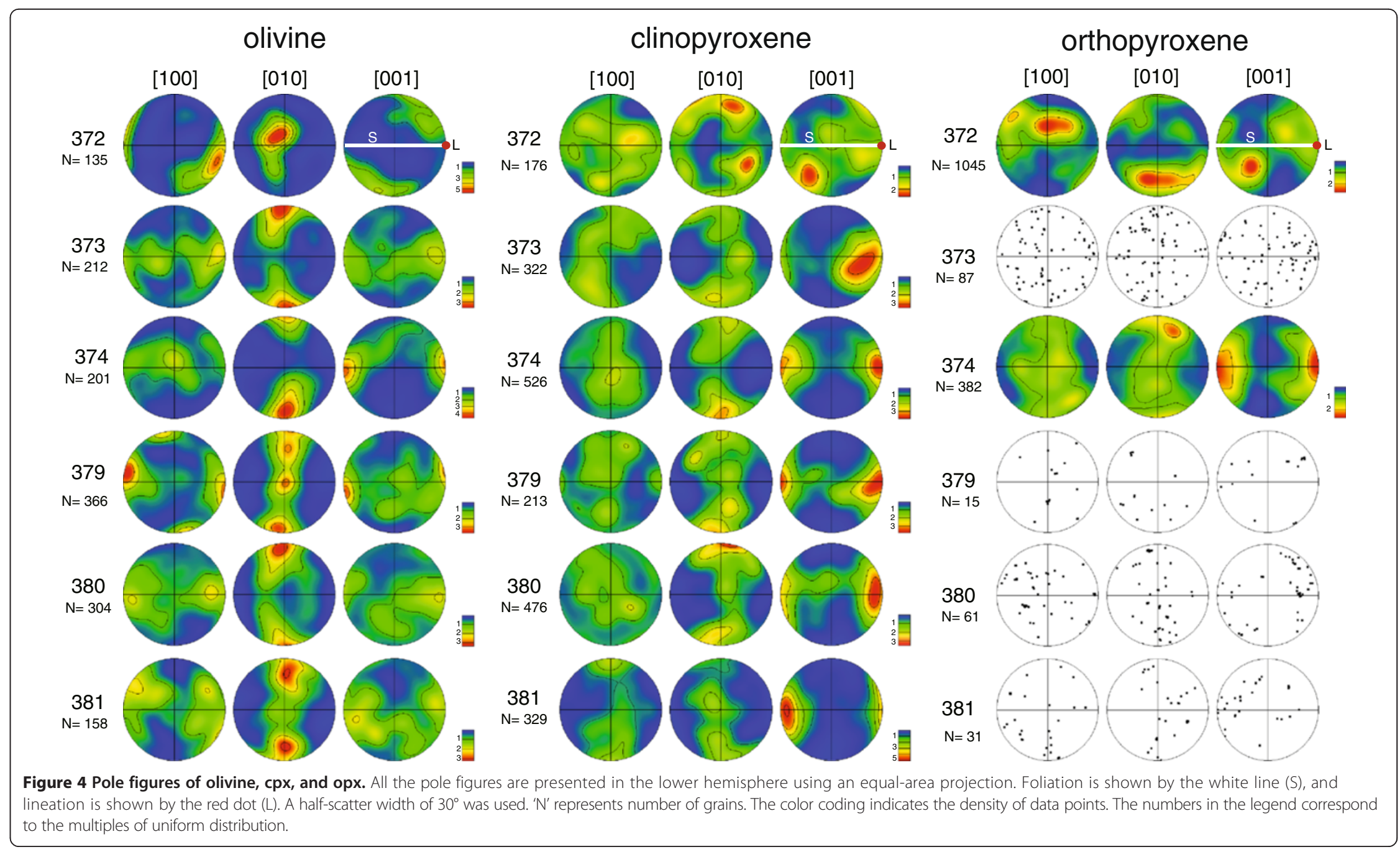




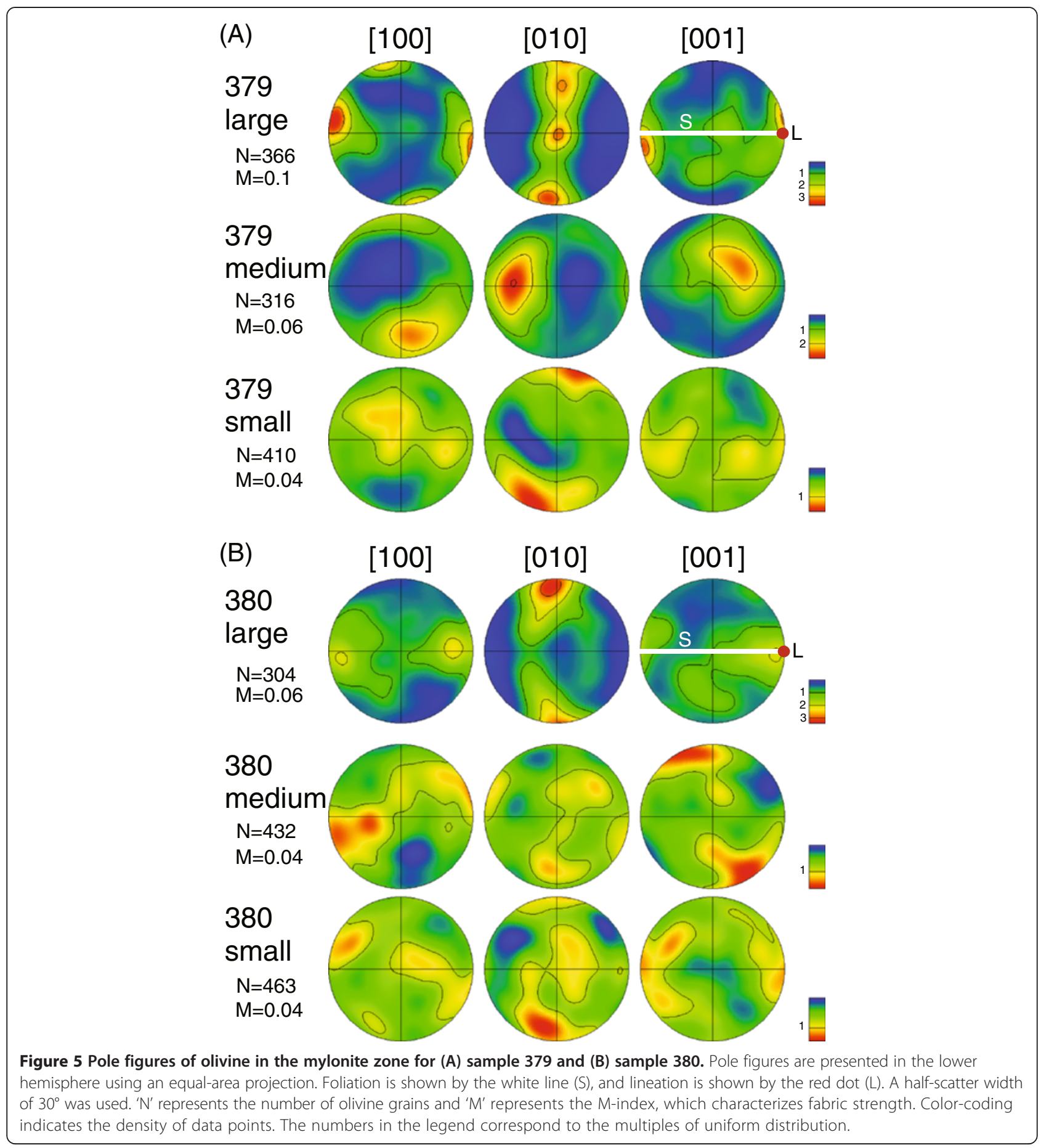

0.04 to 0.06 and was approximately 0.04 for the smallgrained area.

\section{LPO of pyroxene}

The LPO of cpx in wall rocks is plotted in Figure 4. Sample 374 and 380 show that the [001] axes of cpx are aligned subparallel to lineation, and the [010] axes are aligned normal to foliation. This feature is quite similar to the SL-type LPO of omphacite (Boundy et al. 1992; Zhang et al. 2006). Samples 373, 379, and 381 show that the [001] axes are aligned subparallel to lineation, and the [010] and [100] axes form a girdle normal to lineation. This fabric resembles the L-type LPO of omphacite (Zhang et al. 2006). 
The LPO of opx in the wall rock is shown in Figure 4. Sample 372 shows that the [010] axes are aligned subnormal to foliation, the [001] axes of opx are aligned subparallel to lineation, and the [100] axes aligned subnormal to lineation in foliation. This corresponds to the BC-type LPO of opx (Jung et al. 2010). In sample 374, the [001] axes of opx are aligned subparallel to lineation, and both [100] and [010] axes are distributed in a girdle shape normal to lineation. These alignments define the ABC-type LPO of opx (Jung et al. 2010). Samples 373, 379, 380, and 381 did not have enough opx to properly determine the LPO.

\section{Seismic anisotropy and elastic stiffness of specimen}

Seismic anisotropy was calculated on the basis of the LPO data for olivine, opx, and cpx and using the mineral modal composition shown in Table 1. ANIS2k and VpG programs (Mainprice 1990) were used to calculate seismic wave velocity and seismic anisotropy. Elastic constants for singlecrystal olivine (Abramson et al. 1997), opx (Ji and Wang 1999), and cpx (Collins and Brown 1997) were used.

Seismic anisotropy in the wall rocks is shown in Figure 6. The $\mathrm{P}$-wave anisotropy is defined as $\left(\mathrm{Vp}_{\max }-\mathrm{Vp}_{\min }\right) /$ $\mathrm{Vp}_{\text {mean }}$ and ranges $3.2 \%$ to $6.8 \%$, with an average of $4.3 \%$. The maximum amplitude of shear-wave anisotropy ranges $1.94 \%$ to $3.77 \%$, with an average of $2.77 \%$ (Figure 6, Table 1). For the mylonite samples (Figure 7, Table 1), seismic anisotropy tends to weaken as the grain size becomes smaller. In sample 380, the P-wave anisotropy of the large-, medium-, and small-grained areas is $3.4 \%, 2.9 \%$, and $1.4 \%$, respectively (Figure 7, Table 1). In sample 379, the P-wave anisotropy of the large-, medium-, and small-grained areas is $6.8 \%, 7.5 \%$, and $2.2 \%$, respectively (Figure 7 , Table 1 ). The P-wave anisotropy of the medium-grained area of sample 379 was $7.5 \%$, which is a bit higher than that in the largegrained area. This result is thought to be caused by the high modal amount of olivine in the medium-grained area.

We calculated the Vp/Vs ratios based on the LPO data of olivine, opx, and cpx (Table 1). The $\mathrm{Vp} / \mathrm{Vs}$ ratio ranges 1.7 to 1.77 , with an average of 1.73 . This value is higher than the unusually low $\mathrm{Vp} / \mathrm{Vs}$ ratio (1.65) reported by Hacker and Abers (2012), but it is well matched with the result (1.71 to 1.76 ) of that reported by Wagner et al. (2008), which was calculated using the compositions of opxenriched xenoliths from both southern Africa and the Colorado Plateau. Elastic stiffness (Cij) of Vogit-Reuss-Hill average for olivine, orthopyroxene, and clinopyroxene was calculated using the LPO and density of mineral. Elastic stiffness (Cij) of representative samples (372, 373, and 374 ) is shown in Tables 2 and 3.

\section{Water content of olivine}

Water content in optically clean olivine was determined using a Nicolet 6700 FTIR spectrometer, and the results are listed in Table 1. Olivine grains in the wall rock without any optically visible inclusions showed IR absorption peaks at $3,534,3,570,3,589$, and 3,596, which are related to the stretching vibrations of $\mathrm{O}-\mathrm{H}$ bonds, and 3,640, 3,669, 3,675, and $3,688 \mathrm{~cm}^{-1}$, which are related to the nanoscale hydrous minerals like serpentine (Jung 2009) or Ti-clinohumite (Miller et al. 1987; Beran and Libowitzky 2006) (Figure 3A, $B)$. The average water content of olivine in the wall rock calculated using the IR bands between 3,750 and 3,400 cm ${ }^{-1}$ was in the range 110 to $430 \pm 50 \mathrm{ppm} \mathrm{H} / \mathrm{Si}$ (Table 1). Except for the sample 379, the average water content of olivine is greater than $300 \mathrm{ppm} \mathrm{H} / \mathrm{Si}$, which corresponds to a medium water content (Jung et al. 2006). On the other hand, average water content of olivine in the wall rock calculated using the IR bands between 3,620 to $3,500 \mathrm{~cm}^{-1}$ was in the range 90 to $240 \pm 50 \mathrm{ppm} \mathrm{H} / \mathrm{Si}$ (Table 1 ), which reveals that about half of $\mathrm{OH}$ in olivine is preserved as nanoscale hydrous minerals. In addition, we measured water content of coexisting pyroxenes for the samples (373, 374). For the sample 373, water content of pyroxene was high 9,740 $\pm 100 \mathrm{ppm} \mathrm{H} / \mathrm{Si}$ for cpx and 3,620 $\pm 100 \mathrm{ppm}$ $\mathrm{H} / \mathrm{Si}$ for opx. For the sample 374, water content of cpx was also high $9,980 \pm 100 \mathrm{ppm} \mathrm{H} / \mathrm{Si}$ and that of opx was much higher 5,260 $\pm 100 \mathrm{ppm} \mathrm{H} / \mathrm{Si}$ than that of olivine.

The average water content of olivine in mylonite was larger than that of olivine grains in the wall rock. In sample 379 , the average water content of olivine in the wall rock and mylonite was $110 \pm 50 \mathrm{ppm} \mathrm{H} / \mathrm{Si}$ and $600 \pm 50 \mathrm{ppm} \mathrm{H} /$ $\mathrm{Si}$, respectively. In sample 380 , the average water content of olivine in the wall rock and in mylonite was $320 \pm$ $50 \mathrm{ppm} \mathrm{H} / \mathrm{Si}$ and $400 \pm 50 \mathrm{ppm} \mathrm{H} / \mathrm{Si}$, respectively (Table 1 ).

Needle-shaped inclusions were observed in olivine in the wall rock area (samples 372 and 374) and in the mylonite zone (samples 379 and 380) (Figure 3C,D). FTIR analyses were conducted on olivine containing these inclusions to study their impact on the FTIR spectrum. These FTIR spectra for the olivine containing optically visible inclusions in transmitted light were not included for the water content calculation in Table 1. Olivine grains that contained the needle-shaped inclusion showed strong absorption bands in the range 3,400 to $3,750 \mathrm{~cm}^{-1}$ (Figure $3 \mathrm{C}, \mathrm{D}$ ). IR peaks were found at 3,692, 3,688, 3,667, 3,640, and 3,571 $\mathrm{cm}^{-1}$. The strong IR peaks at 3,688 and $3,692 \mathrm{~cm}^{-1}$ indicate the presence of serpentine (Miller et al. 1987; Post and Borer 2000; Khisina et al. 2001; Jung 2009).

\section{Dislocation microstructure}

Backscattered electron images of dislocation microstructures of olivine are shown in Figure 8. All samples in the wall rock area showed a homogeneous distribution of dislocations (Figure 8A,B,C,D). In some cases, straight dislocations were observed (Figure $8 \mathrm{~A}, \mathrm{~B}$ ). Olivine grains in the mylonite zone also showed dislocations (Figures $8 \mathrm{E}$, F,G,H). Dislocations in the medium- and small-grained areas are shown in Figure 8E,G. Both the medium- and 


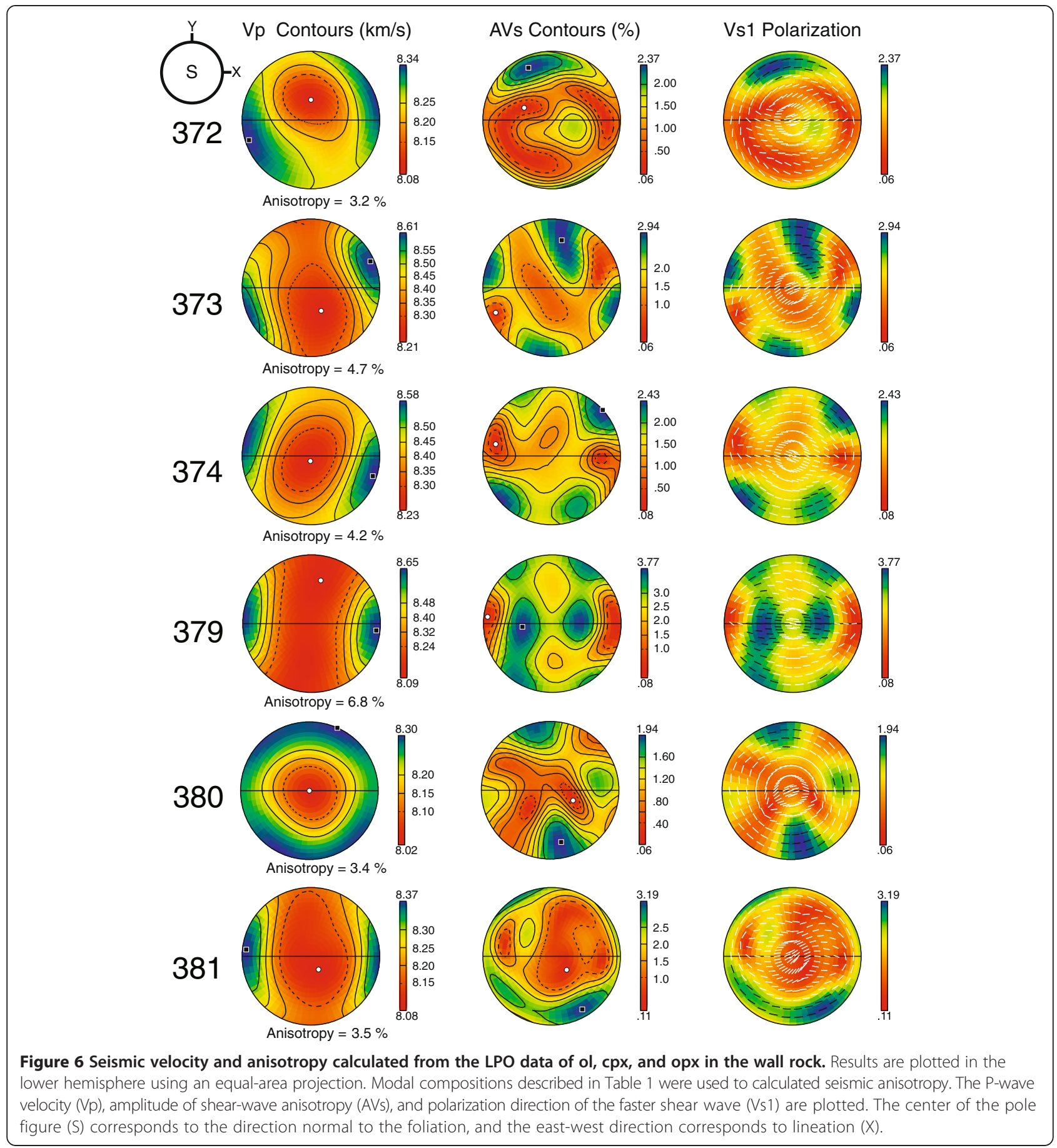

small-grained areas have a lower dislocation density than the large-grained area. The small-grained area showed a heterogeneous distribution of dislocations (Figure 8G), which was observed in a previous experimental study under water-rich conditions (Jung et al. 2006). Four-grain junctions were also found frequently in the small-grained area (Figure $8 \mathrm{H}$ ). The existence of four-grain junctions is evidence of grain-boundary sliding (Ashby and Verral 1973; Karato et al. 1998; Goldsby and Kohlstedt 2001).
Identification of the black inclusion and small minerals

Micro-Raman spectra obtained from various inclusions found in olivine in the wall rock area are plotted in Figure 9. Black colored oxides (Figure 9A) found between olivine grain boundaries show Raman peaks at 865, 832, 678,544 , and $315 \mathrm{~cm}^{-1}$ (Figure 9A). Raman shifts at 865 and $832 \mathrm{~cm}^{-1}$ represent olivine (Guyot et al. 1986), and Raman shifts at 678,544 , and $315 \mathrm{~cm}^{-1}$ represent magnetite (Shebanova and Lazor 2003). Black inclusions found 


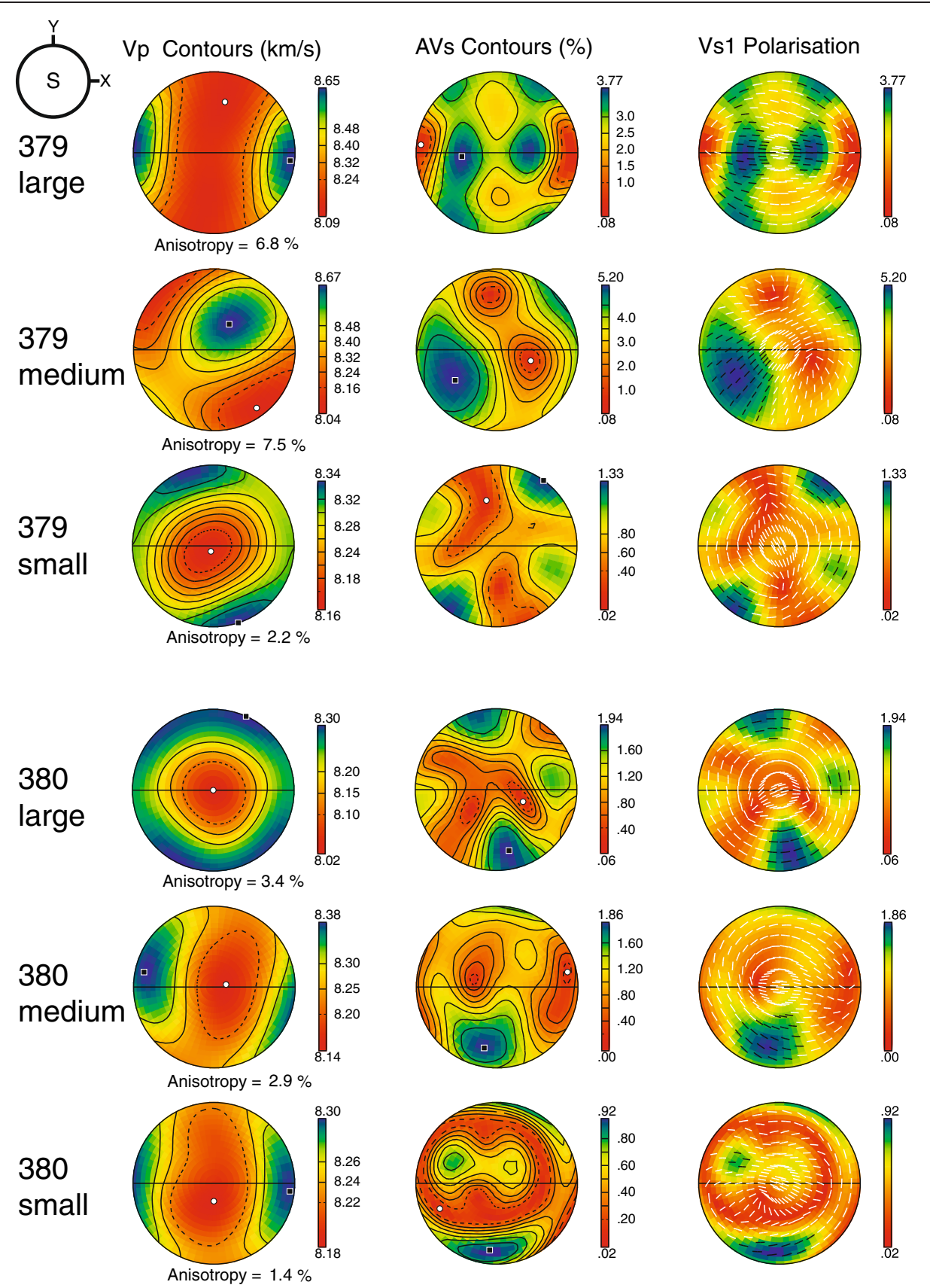

Figure 7 Seismic velocity and anisotropy calculated from the LPO data of olivine and cpx in mylonite zone. Results are plotted in the lower hemisphere using an equal-area projection. Modal compositions described in Table 1 were used to calculated seismic anisotropy. The P-wave velocity (Vp), amplitude of shear-wave anisotropy (AVs), and polarization direction of the faster shear wave (Vs1) are plotted. The center of the pole figure (S) corresponds to the direction normal to the foliation, and the east-west direction corresponds to lineation (X).

inside both olivine and pyroxene grains showed Raman shifts at 678,544 , and $315 \mathrm{~cm}^{-1}$, indicating that the black inclusions are magnetite.

For inclusions in olivine in the medium-grained area of the mylonite, Raman shifts were located at 1,022, 553, 486, 357, and $305 \mathrm{~cm}^{-1}$ (Figure 9B). These Raman peaks represent amosite (Rinaudo et al. 2004). Raman shifts at $685,537,377$, and $224 \mathrm{~cm}^{-1}$ were also observed in the mylonite zone (Figure 9C) and are attributed to antigorite (Rinaudo et al. 2003).

\section{Discussion}

\section{LPO of olivine}

In the large-grained area (wall rock), most samples (373, 379,380 , and 381) showed a combination of A- and B-type LPOs of olivine (Figure 4). In the earlier studies on the 
Table 2 Elastic stiffness, Cij (GPa) of olivine for representative samples $(372,373$, and 374$)$ at ambient condition

\begin{tabular}{|c|c|c|c|c|c|c|}
\hline $\mathbf{i l j}$ & 1 & 2 & 3 & 4 & 5 & 6 \\
\hline \multicolumn{7}{|l|}{$\begin{array}{l}374 \text { olivine } \\
\text { (B-type) }\end{array}$} \\
\hline 1 & 244.8 & 78.36 & 75.35 & 0.52 & 4.36 & 1.72 \\
\hline 2 & & 245.16 & 77.32 & -1.42 & 1.22 & 2.5 \\
\hline 3 & & & 215.71 & -1 & 3.52 & 0.49 \\
\hline 4 & & & & 74.85 & 0.5 & 1.44 \\
\hline 5 & & & & & 76.82 & 0.46 \\
\hline 6 & & & & & & 80.74 \\
\hline Density & $3.355 \mathrm{~g} / \mathrm{cm}^{3}$ & & & & & \\
\hline \multicolumn{7}{|l|}{$\begin{array}{l}372 \text { olivine } \\
\text { (E-type) }\end{array}$} \\
\hline 1 & 213.32 & 74.67 & 77.51 & -1.02 & -3.3 & -5.12 \\
\hline 2 & & 258.02 & 79.98 & 6.91 & -1.27 & -8.09 \\
\hline 3 & & & 234.76 & 4.88 & -5.17 & -2.03 \\
\hline 4 & & & & 82.59 & -3.9 & -3.03 \\
\hline 5 & & & & & 74.52 & 2.68 \\
\hline 6 & & & & & & 76.55 \\
\hline Density & $3.355 \mathrm{~g} / \mathrm{cm}^{3}$ & & & & & \\
\hline \multicolumn{7}{|l|}{$\begin{array}{l}373 \text { olivine } \\
\text { (A + B-type) }\end{array}$} \\
\hline 1 & 236.97 & 79.61 & 75.7 & -0.15 & -0.85 & -1.36 \\
\hline 2 & & 247.23 & 76.25 & -0.87 & -0.65 & -3.3 \\
\hline 3 & & & 219.48 & 0.06 & -0.95 & -0.39 \\
\hline 4 & & & & 76.32 & -0.79 & -0.77 \\
\hline 5 & & & & & 75.26 & -0.21 \\
\hline 6 & & & & & & 81.47 \\
\hline Density & $3.355 \mathrm{~g} / \mathrm{cm}^{3}$ & & & & & \\
\hline
\end{tabular}

Reference axes defined as 2, lineation; 3 , normal to foliation; and 1 , perpendicular to both one and two directions (e.g., $Y=1, X=2, Z=3$ ).

alpine-type peridotite, similar olivine fabrics have been reported from various localities (Prinzhofer et al. 1980; Wedel et al. 1992). These LPOs also resemble the AG-type (Mainprice 2007) or [010]-fiber pattern (Tommasi et al. 1999). The mechanisms proposed for the formation of the AG-type are simultaneous activation of [100] and [001] slip systems (Mainprice et al. 2005; Tommasi et al. 2000), presence of the partial melt (Holtzman et al. 2003), transpression (Tommasi et al. 1999), and recrystallization (Falus et al. 2011). Within these mechanisms, simultaneous activation of [100] and [001] slip direction induced by the presence of water can be the possible mechanism for producing the AG-type LPO in the peridotite samples from the Lindås Nappe complex.

Two major factors are required for changing the slip direction of olivine from [100] to [001] - namely, water (Jung
Table 3 Elastic stiffness, Cij (GPa) of orthopyroxene, clinopyroxene, and combined LPOs of olivine, orthopyroxene, and clinopyroxene

\begin{tabular}{|c|c|c|c|c|c|c|}
\hline $\mathrm{ilj}$ & 1 & 2 & 3 & 4 & 5 & 6 \\
\hline \multicolumn{7}{|c|}{$\begin{array}{l}374 \text { orthopyroxene } \\
\text { (ABC-type) }\end{array}$} \\
\hline 1 & 218.42 & 62.56 & 66.37 & 0.96 & -0.12 & -0.43 \\
\hline 2 & & 223.79 & 62.01 & 0.21 & -0.17 & 0.04 \\
\hline 3 & & & 215.24 & 0.78 & -0.98 & 0.1 \\
\hline 4 & & & & 79.05 & 0.6 & -0.03 \\
\hline 5 & & & & & 75.98 & 0.65 \\
\hline 6 & & & & & & 79.59 \\
\hline Density & $3.306 \mathrm{~g} / \mathrm{cm}^{3}$ & & & & & \\
\hline \multicolumn{7}{|c|}{$\begin{array}{l}374 \text { clinopyroxene } \\
\text { (L-type) }\end{array}$} \\
\hline 1 & 219.03 & 72.6 & 68.73 & 0.39 & -1.95 & 1.29 \\
\hline 2 & & 230.79 & 67.91 & 1.2 & -0.64 & 3.3 \\
\hline 3 & & & 211.51 & 0.03 & -1.45 & 1.4 \\
\hline 4 & & & & 74.43 & 0.72 & 0.18 \\
\hline 5 & & & & & 73.17 & -0.34 \\
\hline 6 & & & & & & 74.37 \\
\hline Density & $3.327 \mathrm{~g} / \mathrm{cm}^{3}$ & & & & & \\
\hline \multicolumn{7}{|c|}{$\begin{array}{l}374 \text { combined } \\
\text { (ol + opx }+ \text { cpx) }\end{array}$} \\
\hline 1 & 223.39 & 70.19 & 69.04 & 0.6 & -0.21 & 0.78 \\
\hline 2 & & 230.9 & 67.59 & 0.39 & -0.15 & 2.07 \\
\hline 3 & & & 213.43 & 0.09 & -0.38 & 0.8 \\
\hline 4 & & & & 76.02 & 0.64 & 0.35 \\
\hline 5 & & & & & 74.77 & 0.13 \\
\hline 6 & & & & & & 77.23 \\
\hline Density & $3.325 \mathrm{~g} / \mathrm{cm}^{3}$ & & & & & \\
\hline
\end{tabular}

Elastic stiffness is calculated for the representative samples (374) at ambient condition. Reference axes defined as 2, lineation; 3, normal to foliation; and 1, perpendicular to both one and two directions (e.g., $Y=1, X=2, Z=3$ ).

and Karato 2001a; Jung et al. 2006) and pressure (Mainprice et al. 2005; Jung et al. 2009; Ohuchi et al. 2011). Of these two factors, pressure is not applicable in this study. Jung et al. (2009) reported that the LPO of olivine changes from A- to B-type at pressures in excess of $3 \mathrm{GPa}$. This pressure corresponds to a depth of approximately $90 \mathrm{~km}$. Ohuchi et al. (2011) also reported that the B-type LPO of olivine was formed at even higher pressures, about $7 \mathrm{GPa}$ at $T=$ $1,220^{\circ} \mathrm{C}$ and $1,400^{\circ} \mathrm{C}$. However, for the anorthosite bodies in the Lindås Nappe complex surrounding the samples, the Grenvillian orogeny occurred at a pressure of $1 \mathrm{GPa}$ and the Caledonian orogeny occurred at 1.5 to $2.1 \mathrm{GPa}$ (Austrheim and Griffin 1985; Glodny et al. 2008; Jamtveit et al. 1990). In both cases, the pressure was less than $3 \mathrm{GPa}$, and hence, pressure alone could not have changed the easiest slip direction of olivine in the study area. 

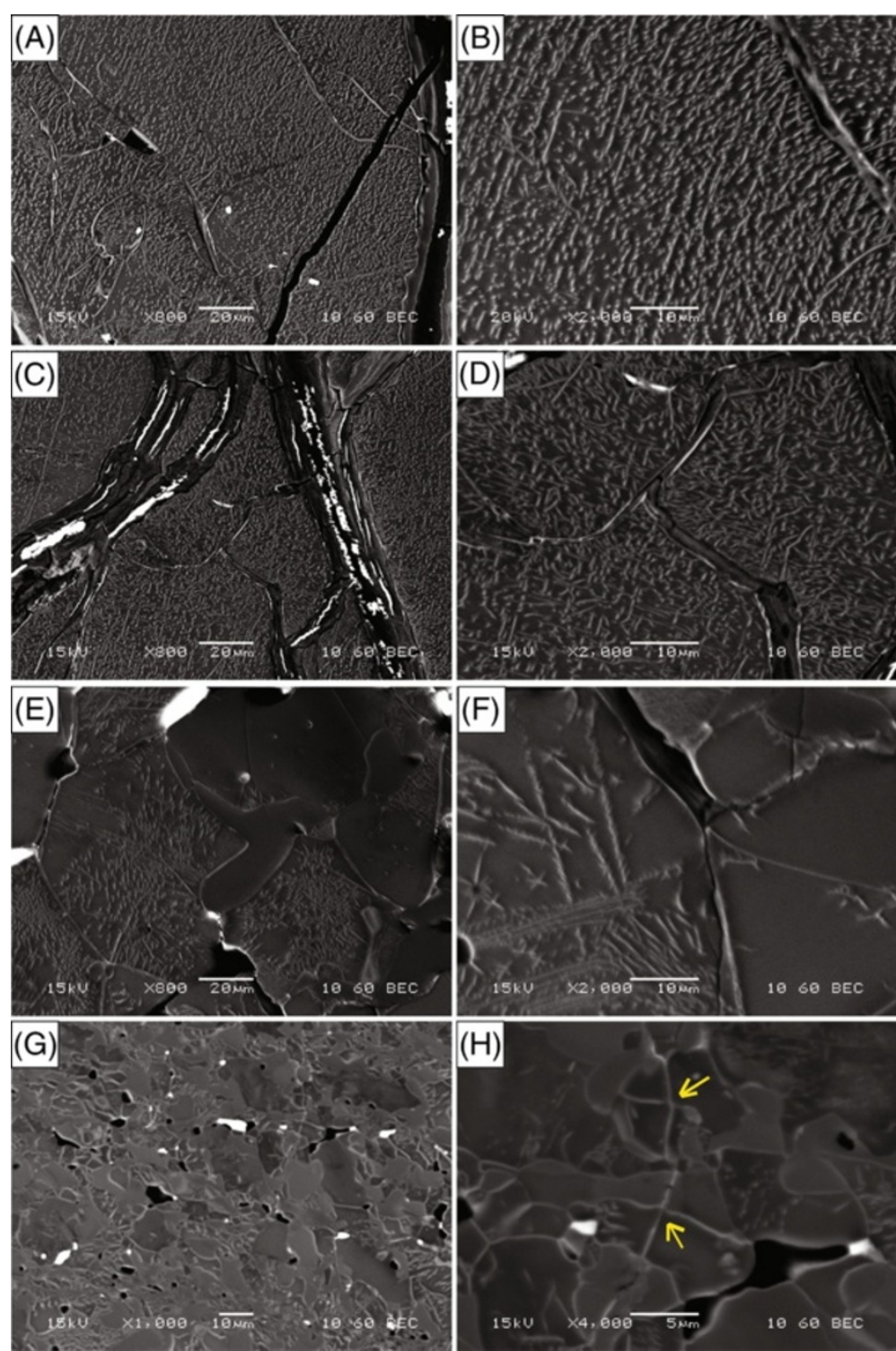

Figure 8 Backscattered electron images showing dislocation microstructures of olivine. Dislocations are shown as white dots and lines. (A) Homogeneous distribution of dislocations in olivine in the large-grained area (sample 372). E-type LPOs are observed from sample 372. (B) Magnified view of Figure 8A. Straight dislocations are observed. (C) Homogeneous distribution of dislocations in olivine in the large-grained area (sample 373). A combination of A- and B-type LPOs are observed. (D) Magnified view of Figure 8C. (E) Dislocation of olivine in the medium-grained area in mylonite (sample 380). (F) Magnified view of Figure 8E. (G) Heterogeneous distribution of dislocations in olivine in the small-grained area in mylonite (sample 380). (H) Four-grain junctions (yellow arrows) found in the small-grained area in mylonite (sample 379).

On the other hand, water is known to change the LPO of olivine (Jung and Karato 2001a). The average water content of olivine in most samples was greater than $300 \mathrm{ppm} \mathrm{H} / \mathrm{Si}$, which is above the boundary differentiating the A-, E-, and B-type LPOs of olivine (Table 1, Figure 10A). In addition, there is substantial evidence of hydrous inclusions in the samples (Figure 3C, $\mathrm{D})$. However, it is hard to tell when exactly $\mathrm{OH}$ is dissolved into olivine, in the Grenvillian orogeny or Caledonian orogeny. Indeed, we found that sample 372 has the E-type LPO of olivine and sample 374 has the B-type
LPO of olivine, which can be interpreted that for the Grenvillian wall rock, LPO of olivine was also produced under the water-rich condition (Jung and Karato 2001a; Katayama et al. 2004; Jung et al. 2006). Water content of coexisting pyroxenes (cpx and opx) in the wall rock was measured and turned out to be very high, 9,740 and 9,980 ppm H/Si for cpx and 3,620 and $5,260 \mathrm{ppm} \mathrm{H} / \mathrm{Si}$ for opx. Because pyroxene has much lower $\mathrm{OH}$ diffusion rate than olivine (Peslier and Luhr 2006), high water content of pyroxene in the Hundskjeften peridotite indicates that original water content of 

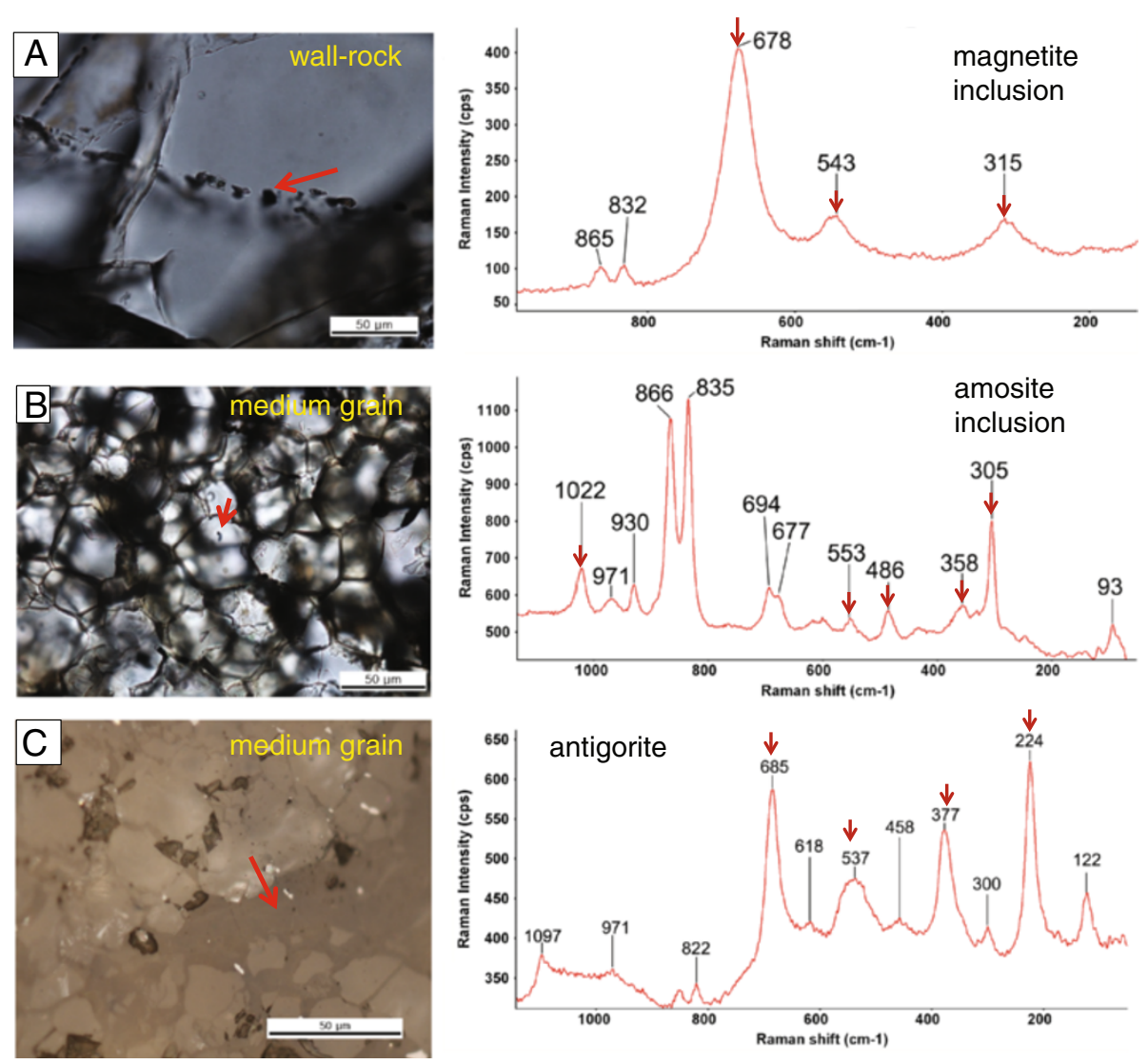

Figure 9 Optical photomicrographs (left) and Raman spectra (right) of inclusions and a hydrous mineral. (A) Black inclusion found inside olivine (sample 379) and a Raman spectrum obtained from the black inclusion. (B) Inclusion found inside olivine in the medium-grained area (sample 379) and a Raman spectrum obtained from the inclusion. (C) Antigorite found in the small-grained area (sample 379) and a Raman spectrum obtained from the antigorite.

olivine at the time of deformation was also higher than the current estimation.

The presence of large amount of pyroxene in the sample might also contribute to change olivine fabric, producing B-type LPO. Sundberg and Cooper (2008) reported that B-type LPO of olivine was produced in diffusion creep when sample contained a large amount of opx (50\%). Sample 374 which showed a nice B-type LPO has high pyroxene content, opx (33\%) and cpx (45\%). But, olivine in the sample 374 has many dislocations indicating that the sample was deformed by dislocation creep. For the small-grained area in our sample 379, opx content was low only $3 \%$, but cpx content was high $33 \%$, producing B-type LPO of olivine. This result indicates that a large amount of cpx ( $\geq 33 \%)$ may also influence olivine fabric.

In the case of E-type LPO of olivine (sample 372), the maximum of [100] axes showed an obliquity, slightly tilted from the lineation (Figure 4), suggesting a dextral sense of shear according to the previous experimental studies (Katayama et al. 2004; Jung et al. 2006) Indeed, outcrop in the field showed the dextral sense of shear (Additional file 2: Figure S2). Similar obliquity of [100] axes of natural olivine with E-type LPO was reported from the Josephine peridotite (Skemer et al. 2010).

The LPO of olivine grains in mylonite was clearly different from that of the large-grained area (wall rock). The differences in the LPO of olivine between the wall rock and mylonite zone can be attributed to the deformation of olivine under a water-rich condition in mylonite. This idea is supported by the FTIR data that show that olivine grains in the medium-grained area in the mylonite zone contain much more water than olivine grains in the large-grained area in the wall rock (Table 1, Figure 10A). Moreover, many hydrous minerals such as antigorite and amosite were observed inside olivine grains in the mediumgrained area (Figure 9). These observations of fabric change induced by water, in the Hundskjeften peridotite, are consistent with previous experimental studies on the deformation of olivine at high pressures and temperatures in the presence of water (Jung and Karato 2001a; Katayama et al. 2004; Jung et al. 2006). Previous studies on surrounding granulite bodies in Bergen Arc report that fluids, which infiltrated through the pseudotachylyte, promoted eclogitization during the Caledonian orogeny (Austrheim 1987, 


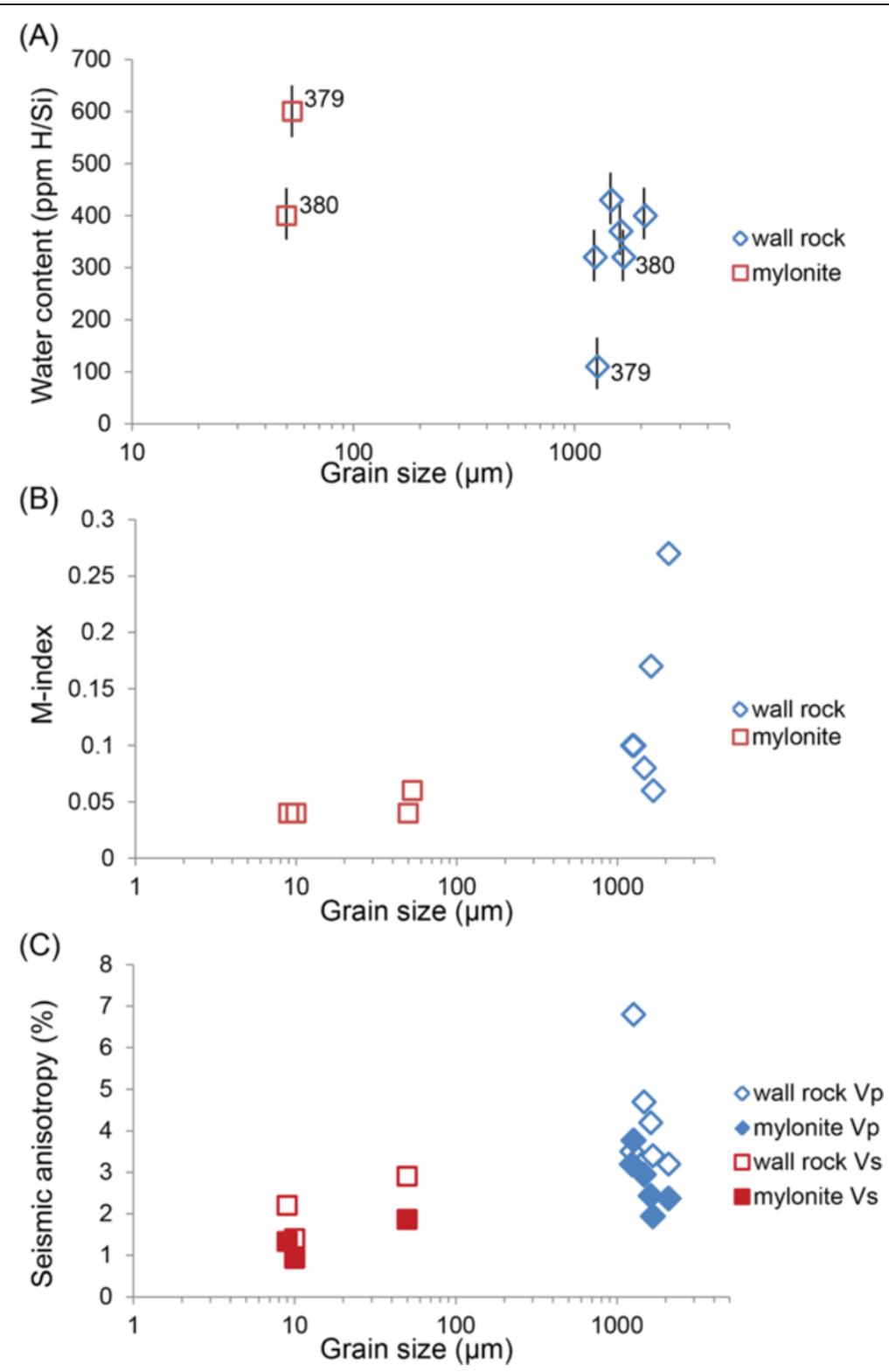

Figure 10 Physical and chemical properties of olivine with respect to average grain size of specimen. (A) Water content of olivine with respect to average grain size. The error bars $( \pm 50 \mathrm{ppm} \mathrm{H} / \mathrm{Si}$ ) of water content are shown as black lines. (B) Fabric strength (M-index) of olivine with respect to average grain size. (C) Maximum Vp and Vs anisotropy with respect to average grain size. Data from a medium-grained area of the specimen 379 was excluded because of its high olivine content.

1990; Austrheim and Boundy 1994; Austrheim et al. 1997). It is also important to consider the possibility that the development of mylonite foliation was associated with reactions that convert spinel lherzolite to garnet lherzolite. The effect of metamorphic reactions on the development of LPOs is unknown and needs further study.

For the medium-grained area of sample 379, [100] axes are aligned subnormal to foliation and the [010] axes are aligned subparallel to lineation (Figure 4a). This is a rare olivine fabric as it requires a [010] Burgers vector. Because axial distance of olivine [010] axis is 10.21 $\AA$, the [010] Burgers vector is difficult to be activated. But, the evidence of the [010] Burgers vector have been reported from the natural and experimental specimen (Phakey et al. 1971; Fujino et al. 1993). Further studies of the natural peridotite and high-pressure experiment will be needed to understand the origin of the olivine fabric with (100) [010] slip system.

It is worth to mention that there is a limitation of the direct application of experimental results to interpret fabrics in natural rocks. High-pressure experiments are 
often performed in a limited set of experimental conditions such as pressure, temperature, water content, stress, strain, and strain rate. Since some of the experimental parameters such as stress, strain, and grain-size are often different from those of natural samples, one needs to be cautious to directly apply experimental results to the natural specimens. To better understand olivine fabrics in nature, further experimental studies at a wide range of P-T condition with varied experimental parameters are needed.

\section{Deformation mechanism}

The fabric strength (M-index) of olivine in the largegrained area (wall rock) is in the range of 0.06 to 0.27 (Table 1, Figure 10B). It is relatively high compared to previous experimental studies (Jung et al. 2006). In some samples (373 and 380), the M-index was lower than 0.1. This low M-index may have resulted from the combination of two different types of LPOs of olivine. As seen in Figure 8, the dislocation density of olivine in the large-grained area is also very high. The strong LPO and high dislocation density of olivine in the wall rock indicate that the dominant deformation mechanism of olivine was dislocation creep.

The mylonite zone shows fabric strength and dislocation microstructures that are different from those of the largegrained area. The M-index tends to be much lower as grain size decreases in the mylonite (Table 1, Figure 10B). In sample 379, the M-index values of the large- (wall rock), medium-, and small-grained areas are 0.1, 0.06, and 0.04 , respectively. In sample 380 , the M-index values of the large-, medium-, and small-grained areas are 0.06, 0.04 , and 0.04 , respectively. It is also found that the dislocation density in the mylonite zone is much lower than that of the large-grained area (Figure 8G,H), and there are four-grain junctions preserved in the small-grained area (Figure $8 \mathrm{H}$ ). A weak LPO and lower dislocation density of olivine and the presence of four-grain junctions in the small-grained area are clear evidence that grain-boundary sliding influenced the deformation of olivine (Hirth and Kohlstedt 1995). A similar change in the deformation mechanism in the mylonite zone has been reported by Drury et al. (1991), Jin et al. (1998), Ueda et al. (2008), Linckens et al. (2011), and Drury et al. (2011).

\section{The mechanism of shear localization}

The mylonite in the Hundskjeften peridotite is a great example of shear localization in the lower crust or mantle condition. In the previous studies, grain size reduction is recognized as one of the most important mechanisms of shear localization in ductile regime (White et al. 1980; Precigout et al. 2007; Raimbourg et al. 2008; Platt and Behr 2011). In case of the Hundskjeften peridotite, there are four possible mechanisms of grain size reduction. One possible explanation is that mylonite forms by grain size reduction through enhanced dynamic recrystallization of olivine in the presence of water. Previous experimental study (Jung and Karato 2001b) showed that water enhances dynamic recrystallization of olivine. Numerous hydrous minerals were found inside mylonite (Figure 3C,D). We also observed B- and E-type LPO of olivine in the mylonite (Figure 5) which can be formed under water-rich conditions (Jung and Karato 2001a; Katayama et al. 2004). These data suggest that enhanced dynamic recrystallization of olivine in the presence of water contributed to the shear localization for the Hundskjeften peridotite. The shear localization enhanced by the water have been reported from several other localities like Fizh massif (Oman) or Josephine Peridotite (SW Oregon, USA) (Michibayashi and Oohara 2013; Skemer et al. 2013).

The other possibility is that the presence of a secondary phase can accelerate shear localization. Previous studies showed that the secondary phase like pyroxenes can cause Zener pinning and slows down the kinetics of grain growth, resulting in the weakening of material and strain localization in the mylonite (Linckens et al. 2011; Farla et al. 2013). The small-grained area in the Hundskjeften peridotite does not contain much opx (less than 5\%) but it has high cpx content (33\% and $45 \%$ ), which might have contributed to reduce grain growth in the mylonite by Zener pinning of cpx, which is believed to result in the shear localization in the peridotite.

The third possible explanation is that the mylonite was originated from the pseudotachylyte veins. In the surrounding anorthositic rock body, there are many pseudotachylyte veins (Austrheim and Boundy 1994; Austrheim et al. 1996) and the mylonite zones can be followed into these pseudotachylyte veins. Also, structure of the mylonite is quite similar to that of the pseudotachylyte: sharp boundary and porphyroclast poor matrix. Exact timing of the pseudotachylyte generation is not clear, but during the Caledonian orogenic event, preexisting pseudotachylyte is reactivated. Increased pressure and temperature during the orogenic event and free fluid channeled through the pseudotachylyte vein-enhanced grain growth, and the mylonite may have evolved from a crystallized frictional melt or ultra-comminuted material (Spray 1995) as described by Ueda et al. (2008). These newly formed small grains act as a weak layer, accelerating shear localization.

The fourth possibility for the localization of shear is due to a shear-induced thermal runaway associated with grain size sensitive creep (Kelemen and Hirth 2007). Strain rate-dependent shear heating and temperaturedependent strain rate accelerate each other as a positive feedback, resulting in rapidly increasing strain rate ending up with shear-heating instability. Kelemen and Hirth (2007) reported that shear can be localized in the preexisting fine-grained shear zone through the shearheating instability associated with grain size-sensitive creep. 


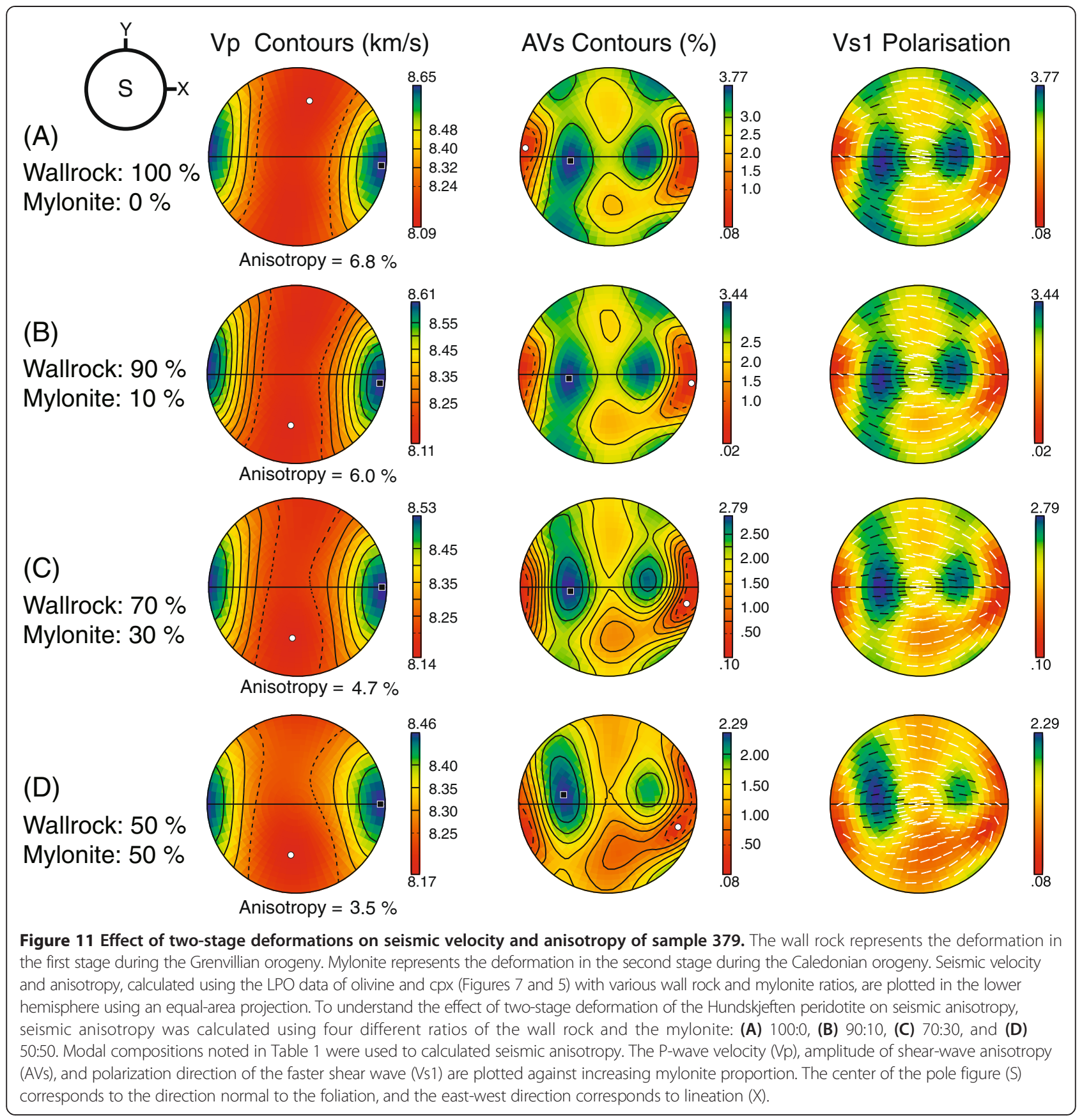

Two-stage deformations and their implications for seismic anisotropy

The Hundskjeften peridotites are believed to have been deformed in two stages: spinel lherzolites in wall rocks were deformed during the Grenvillian orogeny and garnet lherzolites in the mylonite zone were deformed later during the Caledonian orogeny. Spinel grains were found in the wall rock area (Figure 2D), while garnet grains were found in the mylonite zone (Figure $2 \mathrm{H}$ ). This observation suggests that the mylonite part of the samples was deformed in the garnet lherzolite stability field. The phase transition between spinel lherzolite and garnet lherzolite occurs between $1.6 \mathrm{GPa}$ at $800^{\circ} \mathrm{C}$ and $1.9 \mathrm{GPa}$ at $1,100^{\circ} \mathrm{C}\left(\mathrm{O}^{\prime} \mathrm{Neill} 1981\right)$. Pressure was determined to be lower than 1.0 GPa during the Grenvillian orogeny (Austrheim and Griffin 1985) and to range 1.5 to $2.1 \mathrm{GPa}$ during the Caledonian orogeny (Glodny et al. 2008; Jamtveit et al. 1990).

Based on the field observation, metamorphic phases, and LPO of olivine, deformation and metamorphic process during the Caledonian orogeny seems to be highly localized in the mylonite and has almost no effect on the wall 
rock. The boundary between the wall rock and the mylonite is very sharp (Figure 2E,F), and damage zone is limited. The LPO of olivine in wall rock is also well correlated to the foliation of wall rock (Figure 7), suggesting that the LPO of olivine in wall rock was not much affected by the later Caledonian deformation.

Because of weak fabric strength, seismic anisotropy in the mylonite is significantly weaker than that in the wall rock (Table 1, Figure 10C). To understand the effect of two-stage deformation on seismic anisotropy, the seismic anisotropies of peridotites having various wall rock and mylonite ratios were calculated using the LPOs of two dominant minerals, olivine and cpx (Figure 11). We calculated the seismic anisotropy for four different ratios of olivine and cpx using the EBSD data from a representative sample (379). We assumed that $40 \%$ of the mylonite area is medium-grained while $60 \%$ is small-grained.

We found that as the percentage of mylonite (secondstage deformation) increases, both the P-wave and S-wave velocity anisotropy become significantly weaker. This weakening of seismic anisotropy was caused by low fabric strength (M-index) in the mylonite (Figure 5, Table 1) under a water-rich condition. The polarization direction of the fast $\mathrm{S}$-wave did not change much with increasing mylonite proportion (increasing the secondstage deformation).

\section{Conclusions}

Hundskjeften peridotite samples from the Lindås Nappe complex are preserving two fluid-induced fabrics which resulted from two different orogenic events: Grenvillian wall rock fabric (ca. 1,000 Ma) and Caledonian mylonite fabric (ca. $400 \mathrm{Ma}$ ). Compared to the material in the wall rock area, the mylonite has very fine grains and contains many hydrous inclusions (Figures 3D and 9B). Three types of LPOs of olivine are observed in a largegrained area (wall rock): B-type LPO of olivine, E-type LPO of olivine, and A-type + B-type LPO of olivine. In the mylonite zone, there is a change in the LPO of olivine from the wall rock to mylonite; it changes from a combination of A- and B-type LPOs to B- and E-type LPOs of olivine. FTIR analysis of olivine in the largegrained area (wall rock) reveals that the olivine grains have water contents of about $350 \pm 50 \mathrm{ppm} \mathrm{H} / \mathrm{Si}$, which correspond to medium water contents (Jung et al. 2006). Hence, the LPO of olivine in the large-grained area is believed to have originated under conditions of medium water content. The water content of olivine in the mylonite zone is much higher than that of olivine in the wall rock (Table 1). In addition, amosite inclusions and antigorites are found in the mylonite zone. These observations indicate that differences between olivine fabrics of the wall rock and mylonite resulted from differences in water content. Observations of water-induced fabric change in Hundskjeften peridotite are consistent with previous experimental studies of olivine fabrics under water-rich conditions (Jung et al. 2006).

Differences in fabric strength and dislocation density of olivine in the wall rock and mylonite suggest that different deformation mechanisms were involved during the two-stage deformation. A strong LPO and high dislocation density of olivine in the wall rock indicate that the dominant deformation mechanism of olivine was dislocation creep. On the other hand, a weak LPO of olivine, a lower dislocation density of olivine, and fourgrain junctions in the mylonite zone are clear evidence of deformation by dislocation creep accompanied by grain-boundary sliding. Calculating seismic properties in the context of a two-stage deformations, we found that as the percentage of mylonite (second-stage deformation) increases, the P- and S-wave velocity anisotropies become significantly weaker (Figure 11). This study suggests that multi-stage deformations should be examined to better understand seismic anisotropy in the upper mantle and crust.

Mylonite in the peridotite appears to be formed by shear localization in the presence of fluid. Based on our observations of dominant $\mathrm{ol}+\mathrm{cpx}$ and existence of hydrous minerals in the mylonite, we propose that shear can be localized by (1) the reduction of grain size through enhanced dynamic recrystallization of olivine in the presence of water and (2) the reduction of grain growth by Zener pinning of cpx. Shear localization can be also originated from the pseudotachylyte vein.

\section{Additional files}

Additional file 1: Map view of the Hundskjeften peridotite locality

The dotted lines in the P1 and P5 outcrop indicate the mylonite veins.

Samples 372, 373, and 374 were collected from P1 peridotite outcrop, and samples 379, 380, and 381 were collected from P5 peridotite outcrop. This map was modified after Ph.D. thesis of M.G. Lund (2003).

Additional file 2: A picture of the Hundskjeften peridotite outcrop where sense of shear (dextral) is indicated by the white arrows.

\section{Competing interests}

The authors declare that they have no competing interests.

\section{Authors' contributions}

SJ collected the EBSD data, measured water content using FTIR

spectroscopy, and calculated the seismic anisotropy. HJ conceived the study and participated in its design and coordination. $\mathrm{HA}$ and $\mathrm{HJ}$ collected the samples in Bergen Arc. HJ and HA helped to interpret the data and helped to draft the manuscript. SJ wrote the first draft and both $\mathrm{HJ}$ and $\mathrm{HA}$ improved the manuscript. All authors read and approved the final manuscript.

\section{Acknowledgements}

This work was supported by the Mid-career Research Program through an NRF grant to HJ funded by MEST (No. 3345-20100013 and 3345-20130011) in Korea. SJ was partly supported by the Lotte Foundation. HA was supported by a Center of Excellence grant from the Norwegian research Council to PGP. We thank J. Rhie, Y. Kil, H. W. Green, S. Karato, C. Szabó for valuable 
comments, and M. Park, J. Lee, Y. Cao, and B. Ko for their help and discussions, and Mats G. Lund for kindly making unpublished data available to us.

\section{Author details}

${ }^{1}$ School of Earth and Environment Sciences, Seoul National University, Seoul 151-747, South Korea. ${ }^{2}$ Physics of Geological Processes (PGP), University of Oslo, Oslo 0316, Norway.

Received: 15 November 2013 Accepted: 1 May 2014

Published: 2 June 2014

\section{References}

Abramson EH, Brown JM, Slutsky L, Zaug J (1997) The elastic constants of San Carlos olivine to 17 GPa. J Geophys Res 102(B6):12,253-212,263, doi:10.1029/97JB00682

Ashby MF, Verral RA (1973) Diffusion accommodated flow and superplasticity. Acta Metall 21:149-163

Austrheim H (1987) Eclogitization of lower crustal granulites by fluid migration through shear zones. Earth Planet Sci Lett 81(2-3):221-232, doi:10.1016/0012$821 \times(87) 90158-0$

Austrheim H (1990) The granulite-eclogite facies transition: a comparison of experimental work and a natural occurrence in the Bergen Arcs, western Norway. Lithos 25(1-3):163-169, doi:10.1016/0024-4937(90)90012-P

Austrheim H, Boundy TM (1994) Pseudotachylytes generated during seismic faulting and eclogitization of the deep crust. Science 265(5168):82-83, doi:10.1126/science.265.5168.82

Austrheim H, Griffin WL (1985) Shear deformation and eclogite formation within granulite-facies anorthosites of the Bergen arcs, western Norway. Chem Geol 50(1-3):267-281, doi:10.1016/0009-2541(85)90124-X

Austrheim H, Erambert M, Boundy TM (1996) Garnets recording deep crustal earthquakes. Earth Planet Sci Lett 139:223-238

Austrheim H, Erambert M, Engvik AK (1997) Processing of crust in the root of the Caledonian continental collision zone: the role of eclogitization. Tectonophysics 273(1-2):129-153, doi:10.1016/s0040-1951(96)00291-0

Bell DR, Rossman GR, Maldener J, Endisch D, Rauch F (2003) Hydroxide in olivine: a quantitative determination of the absolute amount and calibration of the IR spectrum. J Geophys Res Solid Earth 108(B2):1-9, doi:10.1029/ $2001 j b 000679$

Ben Ismail W, Mainprice D (1998) An olivine fabric database: an overview of upper mantle fabrics and seismic anisotropy. Tectonophysics 296(1-2):145-157

Beran A, Libowitzky E (2006) Water in natural mantle minerals II: olivine, garnet and accessory minerals. Rev Mineral Geochem 62(1):169-191, doi:10.2138/ rmg.2006.62.8

Bingen B, Davis WJ, Austrheim H (2001) Zircon U-Pb geochronology in the Bergen arc eclogites and their Proterozoic protoliths, and implications for the pre-Scandian evolution of the Caledonides in western Norway. Geol Soc Am Bull 113(5):640, doi:10.1130/0016-7606(2001)113<0640:zupgit>2.0.co;2

Boundy TM, Fountain DM, Austrheim H (1992) Structural development and petrofabric of eclogite facies shear zones, Bergen Arcs, western Norway - implications for deep crustal deformational processes. J Metamorph Geol 10(2):127-146, doi:10.1111/j.1525-1314.1992.tb00075.x

Boundy TM, Mezger K, Essene EJ (1997) Temporal and tectonic evolution of the granulite-eclogite association from the Bergen Arcs, western Norway. Lithos 39(3-4):159-178, doi:10.1016/S0024-4937(96)00026-6

Collins MD, Brown JM (1997) Elasticity of an upper mantle clinopyroxene. Phys Chem Miner 26(1):7-13, doi:10.1007/s002690050156

Drury MR, Vissers RLM, Van der Wal D, Strating EHH (1991) Shear localisation in upper mantle peridotites. Pure Appl Geophys 137(4):439-460

Drury MR, Lallemant HGA, Pennock GM, Palasse LN (2011) Crystal preferred orientation in peridotite ultramylonites deformed by grain size sensitive creep, Etang de Lers, Pyrenees, France. J Struct Geol 33(12):1776-1789, doi:10.1016/j.jsg.2011.10.002

Falus G, Tommasi A, Soustelle V (2011) The effect of dynamic recrystallization on olivine crystal preferred orientations in mantle xenoliths deformed under varied stress conditions. J Struct Geol 33(11):1528-1540, doi:10.1016/j.jsg.2011.09.010

Farla RJM, Karato S, Cai Z (2013) Role of orthopyroxene in rheological weakening of the lithosphere via dynamic recrystallization. Proc Natl Acad Sci 110(41):16355-16360, doi:10.1073/pnas.1218335110

Frese K, Trommsdorff V, Kunze K (2003) Olivine 100 normal to foliation: lattice preferred orientation in prograde garnet peridotite formed at high $\mathrm{H} 2 \mathrm{O}$ activity, Cima di Gagnone (Central Alps). Contrib Mineral Petrol 145(1):75-86, doi:10.1007/s00410-002-0434-x
Fujino K, Nakazaki H, Momoi H, Karato S, Kohlstedt DL (1993) TEM observation of dissociated dislocations with $B=010$ in naturally deformed olivine. Phys Earth Planet In 78(1-2):131-137, doi:10.1016/0031-9201(93)90089-r

Gifkins RC (1970) Optical microscopy of metals. Elsevier, New York

Glodny J, Kühn A, Austrheim H (2008) Geochronology of fluid-induced eclogite and amphibolite facies metamorphic reactions in a subduction-collision system, Bergen Arcs, Norway. Contrib Mineral Petrol 156(1):27-48, doi:10.1007/s00410-007-0272-y

Goldsby DL, Kohlstedt DL (2001) Superplastic deformation of ice: experimental observations. J Geophys Res Solid Earth 106(B6):11017-11030, doi:10.1029/ 2000jb900336

Guyot F, Boyer H, Madon M, Velde B, Poirier JP (1986) Comparison of the Raman microprobe spectra of $(\mathrm{Mg}, \mathrm{Fe})_{2} \mathrm{SiO}_{4}$ and $\mathrm{Mg}_{2} \mathrm{GeO}_{4}$ with olivine and spinel structures. Phys Chem Miner 13(2):91-95

Hacker BR, Abers GA (2012) Subduction Factory 5: unusually low Poisson's ratios in subduction zones from elastic anisotropy of peridotite. J Geophys Res Solid Earth 117:15, doi:10.1029/2012jb009187

Hirth G, Kohlstedt DL (1995) Experimental constraints on the dynamics of the partially molten upper mantle: deformation in the diffusion creep regime (1978-2012). J Geophys Res Solid Earth 100(B2):1981-2001, doi:10.1029/94JB02128

Holtzman BK, Kohlstedt DL, Zimmerman ME, Heidelbach F, Hiraga T, Hustoft J (2003) Melt segregation and strain partitioning: implications for seismic anisotropy and mantle flow. Science 301(5637):1227-1230, doi:10.1126/science.1087132

Jamtveit B, Buchernurminen K, Austrheim H (1990) Fluid controlled eclogitization of granulites in deep crustal shear zones, Bergen arcs, western Norway. Contrib Miner Petrol 104(2):184-193, doi:10.1007/bf00306442

Ji S, Wang Z (1999) Elastic properties of forsterite-enstatite composites up to $3.0 \mathrm{GPa}$. J Geodyn 28(2-3):147-174

Jin DH, Karato S, Obata M (1998) Mechanisms of shear localization in the continental lithosphere: inference from the deformation microstructures of peridotites from the Ivrea zone, northwestern Italy. J Struct Geol 20(2-3):195-209, doi:10.1016/ s0191-8141(97)00059-x

Jung H (2009) Deformation fabrics of olivine in Val Malenco peridotite found in Italy and implications for the seismic anisotropy in the upper mantle. Lithos 109(3-4):341-349, doi:10.1016/j.lithos.2008.06.007

Jung $\mathrm{H}$, Karato S (2001a) Water-induced fabric transitions in olivine. Science 293 (5534):1460-1463, doi:10.1126/science.1062235

Jung $\mathrm{H}$, Karato $\mathrm{S}$ (2001b) Effects of water on dynamically recrystallized grain-size of olivine. J Struct Geol 23(9):1337-1344

Jung $H$, Katayama I, Jiang Z, Hiraga T, Karato S (2006) Effect of water and stress on the lattice-preferred orientation of olivine. Tectonophysics 421(1-2):1-22, doi:10.1016/j.tecto.2006.02.011

Jung H, Mo W, Green HW (2009) Upper mantle seismic anisotropy resulting from pressure-induced slip transition in olivine. Nat Geosci 2(1):73-77, doi:10.1038/ ngeo389

Jung H, Park M, Jung S, Lee J (2010) Lattice preferred orientation, water content, and seismic anisotropy of orthopyroxene. J Earth Sci 21(5):555-568, doi:10.1007/s12583-010-0118-9

Jung H, Lee J, Ko B, Jung S, Park M, Cao Y, Song S (2013) Natural type-C olivine fabrics in garnet peridotites in North Qaidam UHP collision belt, NW China. Tectonophysics 594:91-102, doi:10.1016/j.tecto.2013.03.025

Karato S (1987) Scanning electron microscope observation of dislocations in olivine. Phys Chem Miner 14(3):245-248, doi:10.1007/bf00307989

Karato S, Dupas-Bruzek C, Rubie DC (1998) Plastic deformation of silicate spinel under the transition-zone conditions of the Earth's mantle. Nature 395 (6699):266-269, doi:10.1038/26206

Karato S, Jung H, Katayama I, Skemer P (2008) Geodynamic significance of seismic anisotropy of the upper mantle: new insights from laboratory studies. Annu Rev Earth Planet Sci 36(1):59-95, doi:10.1146/annurev.earth.36.031207.124120

Katayama I, Jung H, Karato S (2004) New type of olivine fabric from deformation experiments at modest water content and low stress. Geology 32(12):1045-1048, doi:10.1130/g20805.1

Katayama I, Karato S, Brandon M (2005) Evidence of high water content in the deep upper mantle inferred from deformation microstructures. Geology 33(7):613-616, doi:10.1130/g21332.1

Kelemen PB, Hirth G (2007) A periodic shear-heating mechanism for intermediate-depth earthquakes in the mantle. Nature 446(7137):787-790, doi:10.1038/nature05717

Khisina NR, Wirth R, Andrut M, Ukhanov AV (2001) Extinction and intrinsic mode of hydrogen occurrence in natural olivine: FTIR and TEM investigation. Phys Chem Miner 28:291-301 
Kohlstedt DL, Goetze C, Durham WB, Vandersande J (1976) New technique for decorating dislocations in olivine. Science 191(4231):1045-1046, doi:10.1126/ science.191.4231.1045

Kühn A, Glodny J, Iden K, Austrheim H (2000) Retention of Precambrian RbrSr phlogopite ages through Caledonian eclogite facies metamorphism, Bergen Arc Complex, W-Norway. Lithos 51:305-330

Linckens J, Herwegh M, Muntener O, Mercolli I (2011) Evolution of a polymineralic mantle shear zone and the role of second phases in the localization of deformation. J Geophys Res Solid Earth 116:1-21, doi:B0621010.1029/2010jb008119

Long MD (2013) Constraints on subduction geodynamics from seismic anisotropy. Rev Geophys 51(1):76-112, doi:10.1002/rog.20008

Lund MG (2003) Metamorphism, earthquakes and fracturing of the deep continental crust, PhD Thesis. University of Oslo

Mainprice D (1990) A FORTRAN program to calculate seismic anisotropy from the lattice preferred orientation of minerals. Comput Geosci 16(3):385-393, doi:10.1016/0098-3004(90)90072-2

Mainprice D (2007) Seismic anisotropy of the deep Earth from a mineral and rock physics perspective, vol 2. Treatise on Geophysics, Elsevier, Oxford

Mainprice D, Tommasi A, Couvy H, Cordier P, Frost DJ (2005) Pressure sensitivity of olivine slip systems and seismic anisotropy of Earth's upper mantle. Nature 433(7027):731-733, doi:10.1038/nature03266

Mehl L, Hacker BR, Hirth G, Kelemen PB (2003) Arc-parallel flow within the mantle wedge: evidence from the accreted Talkeetna arc, south central Alaska. J Geophys Res Solid Earth 108(B8):18, doi:10.1029/2002jb002233

Mercier J-CC, Nicolas A (1975) Textures and fabrics of upper-mantle peridotites as illustrated by Xenoliths from basalts. J Petrol 16(1):454-487

Michibayashi K, Oohara T (2013) Olivine fabric evolution in a hydrated ductile shear zone at the Moho transition zone, Oman Ophiolite. Earth Planet Sc Lett 377-378:299-310, doi:10.1016/j.epsl.2013.07.00

Michibayashi K, Tasaka M, Ohara Y, Ishii T, Okamoto A, Fryer P (2007) Variable microstructure of peridotite samples from the southern Mariana trench: evidence of a complex tectonic evolution. Tectonophysics 444(1-4):111-118, doi:10.1016/j.tecto.2007.08.010

Miller GH, Rossman GR, Harlow GE (1987) The natural occurrence of hydroxide in olivine. Phys Chem Miner 14(5):461-472, doi:10.1007/bf00628824

Nesse WD (2004) Introduction to optical mineralogy. Oxford University Press, New York

Nicolas A, Christensen NI (1987) Formation of anisotropy in upper mantle peridotites: a review. Geodyn Ser 16:111-123, doi:10.1029/GD016p0111

O'Neill HSC (1981) The transition between spinel Iherzolite and garnet Iherzolite, and its use as a geobarometer. Contrib Miner Petrol 77(2):185-194, doi:10.1007/bf00636522

Ohuchi T, Kawazoe T, Nishihara Y, Nishiyama N, Irifune T (2011) High pressure and temperature fabric transitions in olivine and variations in upper mantle seismic anisotropy. Earth Planet Sci Lett 304(1-2):55-63, doi:10.1016/j. epsl.2011.01.015

Panozzo R (1984) Two-dimensional strain from the orientation of lines in a plane. J Struct Geol 6(l-2):215-221

Park Y, Jung H (2014) Deformation microstructures of olivine and pyroxene in mantle xenoliths in Shanwang, eastern China, near the convergent plate margin and implications for seismic anisotropy. Int Geol Rev. in press

Park M, Jung H, Kil Y (2014) Petrofabrics of olivine in a rift axis and rift shoulder and their implications for seismic anisotropy under the Rio Grande rift. Island Arc, in press

Paterson MS (1982) The determination of hydroxyl by infrared-absorption in quartz, silicate-glasses and similar materials. Bull Mineral 105(1):20-29

Peslier AH, Luhr JF (2006) Hydrogen loss from olivines in mantle xenoliths from Simcoe (USA) and Mexico: Mafic alkalic magma ascent rates and water budget of the sub-continental lithosphere. Earth Planet Sci Lett 242(3-4):302-319, doi:10.1016/j.epsl.2005.12.019

Phakey PP, Dollinge G, Christie JM (1971) Transmission electron microscopy of experimentally deformed olivine crystals. Trans Am Geophys Union 52(11):919

Platt JP, Behr WM (2011) Grainsize evolution in ductile shear zones: implications for strain localization and the strength of the lithosphere. J Struct Geol 33(4):537-550, doi:10.1016/j.jsg.2011.01.018

Pollok K, Lloyd GE, Austrheim H, Putnis A (2008) Complex replacement patterns in garnets from Bergen Arcs eclogites: a combined EBSD and analytical TEM study. Chem Erde-Geochem 68(2):177-191, doi:10.1016/j.chemer.2007.12.002
Post JL, Borer L (2000) High-resolution infrared spectra, physical properties, and micromorphology of serpentines. Appl Clay Sci 16:73-85

Precigout J, Gueydan F, Gapais D, Garrido CJ, Essaifi A (2007) Strain localisation in the subcontinental mantle - a ductile alternative to the brittle mantle. Tectonophysics 445(3-4):318-336, doi:10.1016/j. tecto.2007.09.002

Prinzhofer A, Nicolas A, Cassard D, Moutte J, Leblanc M, Paris JP, Rabinovitch M (1980) Structures in the New-Caledonia peridotites-gabbros: implications for oceanic mantle and crust. Tectonophysics 69(1-2):85-112, doi:10.1016/00401951(80)90128-6

Raimbourg H, Toyoshima T, Harima Y, Kimura G (2008) Grain-size reduction mechanisms and rheological consequences in high-temperature gabbro mylonites of Hidaka, Japan. Earth Planet Sci Lett 267(3-4):637-653, doi:10.1016/j.epsl.2007.12.012

Rinaudo C, Gastaldi D, Belluso E (2003) Characterization of chrysotile, antigorite, and lizardite by FT-Raman spectroscopy. Can Mineral 41(4):883-890, doi:10.2113/gscanmin.41.4.883

Rinaudo C, Belluso E, Gastaldi D (2004) Assessment of the use of Raman spectroscopy for the determination of amphibole asbestos. Mineral Mag 68(3):455-465, doi:10.1180/0026461046830197

Shebanova ON, Lazor P (2003) Raman spectroscopic study of magnetite (FeFe2O4): a new assignment for the vibrational spectrum. J Solid State Chem 174(2):424-430, doi:10.1016/s0022-4596(03)00294-9

Skemer P, Katayama I, Jiang Z, Karato S (2005) The misorientation index: development of a new method for calculating the strength of lattice-preferred orientation. Tectonophysics 411(1-4):157-167, doi:10.1016/j.tecto.2005.08.023

Skemer P, Warren JM, Kelemen PB, Hirth G (2010) Microstructural and rheological evolution of a mantle shear zone. J Petrol 51(1-2):43-53, doi:10.1093/ petrology/egp057

Skemer P, Warren JM, Hansen LN, Hirth G, Kelemen PB (2013) The influence of water and LPO on the initiation and evolution of mantle shear zones. Earth Planet Sci Lett 375:222-233, doi:10.1016/j.epsl.2013.05.034

Spray JG (1995) Pseudotachylyte controversy: fact or friction? Geology 23 (12):1119-1122, doi:10.1130/0091-7613(1995)023<1119:PCFOF>2.3.CO;2

Sundberg M, Cooper RF (2008) Crystallographic preferred orientation produced by diffusional creep of harzburgite: effects of chemical interactions among phases during plastic flow. J Geophys Res Solid Earth 113(B12):16, doi:10.1029/2008jb005618

Tommasi A, Tikoff B, Vauchez A (1999) Upper mantle tectonics: threedimensional deformation, olivine crystallographic fabrics and seismic properties. Earth Planet Sci Lett 168(1-2):173-186, doi:10.1016/s0012-821x (99)00046-1

Tommasi A, Mainprice D, Canova G, Chastel Y (2000) Viscoplastic self-consistent and equilibrium-based modeling of olivine lattice preferred orientations: implications for the upper mantle seismic anisotropy. J Geophys Res Solid Earth 105(B4):7893-7908, doi:10.1029/1999jb900411

Ueda T, Obata M, Di Toro G, Kanagawa K, Ozawa K (2008) Mantle earthquakes frozen in mylonitized ultramafic pseudotachylytes of spinel-Iherzolite facies. Geology 36(8):607-610, doi:10.1130/g24739a.1

Wagner LS, Anderson ML, Jackson JM, Beck SL, Zandt G (2008) Seismic evidence for orthopyroxene enrichment in the continental lithosphere. Geology 36(12):935-938, doi:10.1130/g25108a.1

Webber C, Little T, Newman J, Tikoff B (2008) Fabric superposition in upper mantle peridotite, Red Hills, New Zealand. J Struct Geol 30(11):1412-1428, doi:10.1016/j.jsg.2008.08.002

Wedel A, Skrotzki W, Weber K (1992) Microstructure and texture in peridotite xenoliths from the Hessian depression. Geotekt Forsch 78:89-125

White SH, Burrows SE, Carreras J, Shaw ND, Humphreys FJ (1980) On mylonites in ductile shear zones. J Struct Geol 2(1-2):175, doi:10.1016/0191-8141(80) 90048-6

Zhang JF, Green HW, Bozhilov KN (2006) Rheology of omphacite at high temperature and pressure and significance of its lattice preferred orientations. Earth Planet Sci Lett 246(3-4):432-443, doi:10.1016/j. epsl.2006.04.006

\section{doi:10.1186/1880-5981-66-46}

Cite this article as: Jung et al:: Characterization of olivine fabrics and mylonite in the presence of fluid and implications for seismic anisotropy and shear localization. Earth, Planets and Space 2014 66:46. 